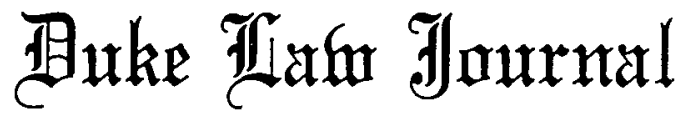

\section{FRIVOLOUS APPEALS: THE UNCERTAIN FEDERAL RESPONSE}

\author{
RoBert J. MARTINEAU*
}

\begin{abstract}
Frivolous appeals and abusive appeal tactics contribute to the enormous workload of the federal courts of appeals. Because these courts have been unsuccessful in defining clearly when and under what circumstances they will impose sanctions for frivolous appeals or abusive appeal tactics, the deterrent effect of these sanctions has been minimal. Professor Martineau proposes a new rule requiring sanctions for either frivolous appeals or abusive appeal tactics, arguing that sanctions are necessary to protect both litigants and the ability of the federal appellate courts to decide cases in an expeditious and fair manner.
\end{abstract}

\section{INTRODUCTION}

Between 1961 and 1983, the number of appeals commenced in the United States Courts of Appeals increased by 705 percent. ${ }^{1}$ The number of authorized judgeships, however, increased by only one hundred percent. ${ }^{2}$ During the twelve month period ending on June 30,

* Professor of Law, University of Cincinnati. Author, Modern Appellate PracticeFederal and State Civil Appeals (1983); Circuit Executive, U.S. Court of Appeals, Eighth Circuit (1972-74). The author is greatly indebted to Patricia Davidson for assistance in the preparation of the text and footnotes and Barbara Tesch for assistance in the preparation of the footnotes.

1. In 1961, 4204 appeals were filed. See Director of THE ADMINISTRATIVE OfFICE of THE UNITED STATES CouRTS, 1961 ANNUAL RePORT 115 [hereinafter cited as 1961 CouRT REPORT]. By 1983, the number of appeals had risen to 29,630. See DirEctor of THE AdMINISTRATIVE OFFICE OF THE UNITED STATES COURTS, 1983 ANNUAL REPORT 97 [hereinafter cited as 1983 COURT REPORT].

2. See 1961 Court Report, supra note 1, at 116; 1983 Court RePort, supra note 1, at 97. The number of authorized circuit judgeships has been increased periodically since 1961 . The inost recent increase was froin 97 to 132 in 1978. See 28 U.S.C. \& 44(a) (1982), as amended by Act of Oct. 20, 1978, Pub. L. No. 95-486, $\S 3($ a), 92 Stat. 1629, 1632. Recently, Congress, as part of the reconstitution of the bankruptcy court system, created 24 additional circuit judgeships. See Bankruptcy Amendments and Federal Judgeship Act of 1984, Pub. L. No. 98-353, § 201, 98 Stat. 333, 346-47. 
1983, nearly 30,000 appeals were filed in the circuit courts. ${ }^{3}$ Both courts and commentators have warned that this flood of appeals is a threat to an effective federal appellate system. ${ }^{4}$ Many scholars have proposed structural or jurisdictional changes to the federal appellate system, but the only major response to date has been the division of the Fifth Circuit into the Fifth and Eleventh Circuits. ${ }^{5}$ The creation of thirty-five new circuit judgeships in $1978^{6}$ was not intended as a longterm solution to the problein, but was simply one response to burgeoning caseloads.

The federal appeals courts have been forced to develop new techniques for disposing of substantially more cases with only a marginal increase in the number of judges. Many changes in operating procedures have dramatically imcreased the output of federal appellate courts. These changes include dispositions without oral arguinent or without written opinion or with neither, dispositions from the bench

3. 1983 CoURT REPORT, supra note 1 , at 97 .

4. See, e.g., WSM, Inc. v. Tennessee Sales Co., 709 F.2d 1084, 1088 (6th Cir. 1983); NLRB v. Lucy Ellen Candy Div. of F\&F Laboratories, Inc., 517 F.2d 551, 554-55 (7th Cir. 1975); Furbee v. Vantage Press, Inc., 464 F.2d 835, 837 (D.C. Cir. 1972); P. Carrungton, D. Meador \& M. Rosengerg, Justice on Appeal 4-7 (1976); R. Martineau, Modern appellate Practice: Federal and STATE Civil Appeals § 1.2, at 10 (1983); D. Meador, Appellate Courts STAfF AND Process IN THE CRISIS OF Volume 7-9 (1974); Meador, The Federal Judiciary-Infation, Malfunction, and a Proposed Course of Action, 1981 B.Y.U. L. Rev. 617, 618-21; Posner, Will the Federal Courts of Appeals Survive Until 1984: An Essay on Delegation and Specialization of the Judicial Function, 56 S. CAL. L. Rev. 761, 761-67 (1983); Silas, Circuit Breaker, 70 A.B.A. J. 34,34 (1984).

5. 28 U.S.C. $\S 41$ (1982), as amended by Act of Oct. 14, 1980, Pub. L. No. $96-452$, § 2, 94 Stat. 1994. In 1982, Congress also created the U.S. Court of Appeals for the Federal Circuit by joining the appellate division of the Court of Claims with the Court of Customs and Patent Appeals. Federal Courts Improvement Act of 1982, Pub. L. No. 97-164, 96 Stat. 25. For various proposals, see, for example, American Bar Association Task Force on Appellate ProceDURE, EfFiciency and Justice IN Appeals: Methods and Selected Materials (1977) (calling for various penalties for frivolous appeals), evaluated in Note, Disincentives to Frivolous Appeals: An Evaluation of an ABA Task Force Proposal, 64 VA. L. REv. 605, $611-24$ (1978); COMmission on Revision of the Federal Court Appellate SyStem, Structure ANd INTERNal Procedures: ReCOMMENDATIONS For Change (1975); H. Friendly, Federal JuRISDiction: A GENERAL VIEW 197 (1973) (recommending structural changes); Friendly, Averting the Flood by Lessening the Flow, 59 CORNELl L. REv. 634, 640-57 (1974) (proposing structural and jurisdictional changes); Godbold, Improvements in Appellate Procedure: Better Use of Available Facilities, 66 A.B.A. J. 863 (1980) (calling for procedural modifications); Griswold, Helping the Supreme Court by Reducing the Flow of Cases into the Courts of Appeals, 67 JudiCATURE 58, 60-66 (1983) (proposing structural changes and an increase in the number of specialized federal courts); Philhips, Diversity Jurisdiction: Problems and a Possible Solution, 14 U. ToL. L. Rev. 747 (1983) (arguing that ultimate solution to flood of appeals would be the repeal of diversity jurisdiction).

In a recent speech criticizing the cost and delay involved in hitigation, Justice William Rehnquist proposed the elimination of automatic appeals from the trial courts, suggesting that appellate review be allowed "only where it is granted in the discretion of a panel of the appellate court." (quoted in N.Y. Times, Sept. 15, 1984, at 27, col. 1.)

6. See supra note 2 . 
immediately following oral argument, disposition on motion, settlement conferences, use of central staff, and additional personal law clerks for the judges. ${ }^{7}$

These judicial efforts have focused solely on one aspect of the appellate process-the number of cases terminated by the courts of appeals. Far less attention has been paid to reducing the number of appeals coming to the appellate courts. The few proposals that seek to reduce the number of appeals have primarily suggested reducing the jurisdiction of the federal district courts-diversity and habeas corpus are the most common targets-rather than restricting the appealability of district court decisions. ${ }^{8}$ These proposals almost invariably require legislative action because they affect jurisdiction. ${ }^{9}$

The federal courts of appeals are unable to change their own jurisdiction and thus can impose no major limitation on the number of appeals coming to them. ${ }^{10}$ In the past several years, however, these courts have rehed increasingly upon the authority granted to them by two statutes $^{11}$ and a federal rule of appellate procedure ${ }^{12}$ to impose sanctions upon parties or attorneys taking frivolous appeals or using abusive tactics during the pendency of an appeal. ${ }^{13}$

The courts of appeals have set forth three principal purposes to be achieved by the imposition of sanctions. The immediate objectives are to compensate the opposing party for the time and expense that he has

7. See, e.g., R. MARTINEAU, supra note 4, $\$ 1.3$, at 11 (observing that role of oral argument, publication of opinions, and other aspects of system are subject to change); Godbold, supra note 5 , at 864 (discussing Fifth Circuit's limit on oral argument); Posner, supra note 4, at 767-75 (discussing law clerks and staff attorneys).

8. See Friendly, supra note 5, at 640-46 (elimination of diversity jurisdiction and other jurisdictional changes); Griswold, supra note 5, at 65-66 (creating specialized appellate tribunals); Phillips, supra note 5 , at $749-56$ \& 749 n.6.

9. See Sheldon v. Sill, 49 U.S. (8 How.) $441,448-49$ (1850) ("Congress, having the power to establish the courts, must define their respective jurisdictions."). See generally M. REDISH, FEDeral JuRisdiction: Tensions in the Allocation of Judicial Power 21-24 (1980). The Supreme Court's decisions restricting the availability of habeas corpus to state prisoners challenging their convictions or the conditions of their confinement may have a similar effect. See Wainwright v. Sykes, 433 U.S. 72, 86-87 (1977) (barring habeas corpus review when petitioner, without excuse, failed to raise objection); Stone v. Powell, 428 U.S. 465,494 (1976) (no right to habeas corpus clain after fourth amendment challenge was fully and fairly hitigated).

10. See Coopers \& Lybrand v. Livesay, 437 U.S. 463, 476 \& n.28 (1978) (Congress is to decide clianges in jurisdiction).

11. 28 U.S.C. $\S \S 1912,1927$ (1982). See infra notes 68 and 70.

12. FED. R. APP. P. 38.

13. See Annot., 67 A.L.R. FED. 319 (1984). States have also addressed this problem. See, Annot., 91 A.L.R.3D 661, 664 (1979); Comment, Mandatory Assessment of Damages Against an Unsuccessful Appellant: A Constitutional Analysis, 53 Miss. L.J. 281, $281-82$ (1983). 
incurred ${ }^{14}$ and to punish the offending person for wasting the limited time and resources of the appellate court. ${ }^{15}$ The long-term objective is deterrence ${ }^{16}$-reducing the number of appeals taken to the courts of appeals and the ainount of time spent on appeals. ${ }^{17}$ Deterring frivolous appeals serves another purpose-protecting litigants in other cases whose appeals are delayed because the court is spending time on the frivolous appeals. ${ }^{18}$ Compensation will more likely be the objective when the appellee files a inotion seeking a nonetary award, while deterrence will be cited more often when the court raises the issue sua sponte. ${ }^{19}$

The use of sanctions to penalize appellants and their attorneys is not without difficulty. The fear of a sanction may discourage a person

14. See, e.g., Nevijel v. North Coast Life Ins. Co., 651 F.2d 671, 675 (9th Cir. 1981) (defendant has a right to be free from costly, frivolous suits); Ruderer v. Fines, 614 F.2d 1128, 1132 (7th Cir. 1980) (one goal is compensation). For decisions awarding costs of defending a frivolous appeal, see, for example, Bank of Canton v. Republic Nat'1 Bank, 636 F.2d 30, 31 (2d Cir. 1980); Self v. Self, 614 F.2d 1026, 1028 (5th Cir. 1980); Exhibitors Poster Exch., Ine. v. National Screen Serv. Corp., 543 F.2d 1106, 1107 (5th Cir.), cert. denied, 431 U.S. 938 (1977); Clarion Corp. v. American Home Prod. Corp., 494 F.2d 860, 865-66 (7th Cir.), cert. denied, 419 U.S. 870 (1974); Fluoro Elec. Corp. v. Branford Assoc., 489 F.2d 320, 326 (2d Cir. 1973); Oscar Gruss \& Son v. Lumbermens Mut. Casualty Co., 422 F.2d 1278, 1284 (2d Cir. 1970); Lowe v. Willacy, 239 F.2d 179, 180 (9th Cir. 1956) (per curiam).

15. For decisions penalizing frivolous appeals, see, for example, WSM, Inc. v. Tennessee Sales Co., 709 F.2d 1084, 1088 (6th Cir. 1983); Van Amem Co. v. CIS Leasing Corp., Nos. 801258, 80-1275 (6th Cir. Jan. 5, 1982) (available Aug. 1, 1983, on LEXIS, Genfed library, Cir file) (double appellate costs assessed agamst party for unnecessarily wasting the time and resources of the court); Asberry v. United States Postal Serv., 692 F.2d 1378, 1382 (Fed. Cir. 1982); Simon \& Flynn, Inc. v. Time, Inc., 513 F.2d 832, 834-35 (2d Cir. 1975); Clarion Corp. v. American Home Prod. Corp., 494 F.2d 860, 865-66 (7th Cir.), cert. denied, 419 U.S. 870 (1974); Fluoro Elec. Corp. v. Branford Assoc., 489 F.2d 320, 326 (2d Cir. 1973); NLRB v. Smith \& Wesson, 424 F.2d 1072, 1073 (1st Cir. 1970).

16. See, e.g., Hutto v. Finney, 437 U.S. 678, 691 (1977); Whitney v. Cook, 99 U.S. 607, 607 (1879); Seyler v. Seyler, 678 F.2d 29, 31 (5th Cir. 1982) (quoting Whitney, 99 U.S. at 607); McConnell v. Critchlow, 661 F.2d 116, 118 (9th Cir. 1981); Ruderer v. Fines, 614 F.2d 1128, 1132 (7th Cir. 1980).

17. Ruderer v. Fines, 614 F.2d 1128, 1132 (7th Cir. 1980).

18. Oberman, Federal Courts Commentary-Coping With the Rising Caseload II: Defining the Frivolous Civil Appeal, 47 BRookLYN L. REv. 1057, 1058 (1981); see Nevijel v. North Coast Life Ins. Co., 651 F.2d 671, 675 (9th Cir. 1981); Ruderer v. Fines, 614 F.2d 1128, 1132 (7th Cir. 1980); In re Bithoney, 486 F.2d 319, 322 (1st Cir. 1973).

19. Compare Fluoro Elec. Corp. v. Branford Assoc., 489 F.2d 320, 326 (2d Cir. 1973) (damages granted in response to plaintiffs motion to compensate for expenses in answering wholly frivolous appeal) and Self v. Self, 614 F.2d 1026, 1028 (5th Cir. 1980) (court awarded damages pursuant to appellee's motion to compensate for costs incurred by frivolous appeal) with Ruderer v. Fines, 614 F.2d 1128, 1132 (7th Cir. 1980) (court demied motion because penalty goes beyond coinpensation to deterrence of other such appeals) and Van Amein Co. v. CIS Leasing Corp., Nos. 80-1258, 80-1275 (6th Cir. Jan. 5, 1982) (available Aug. 1, 1983, on LEXIS, Genfed library, Cir file) (court will award costs sua sponte under extraordinary circumstances to penalize party for wasting time of court). 
with a valid claim from pursuimg it on appeal.20 Although this danger may exist even if it were clear when and under what circumstances a sanction would be imposed, it is heightened substantially when there are several different sources of authority for imposing a sanction, ${ }^{21}$ when there are multiple purposes for the sanction, ${ }^{22}$ when varyimg standards are used in judging whether an appeal is frivolous, ${ }^{23}$ when the relationship between frivolous appeal sanctions and abusive litigation tactics is unclear, ${ }^{24}$ when the sanction is imposed without notice or an opportumity to be heard, ${ }^{25}$ and when the procedure varies for initiating consideration of a sanction. ${ }^{26}$

Because of these uncertamties, it is imperative that when courts impose sanctions for frivolous appeals, they do so in accord with a procedure that is consistent with due process requirements. It is also essential that courts develop a clearly articulated definition of frivolous appeals, indicating, in particular, whether an objective or subjective standard is used. Further, they must clearly distinguish between (1) a sanction imposed for taking a meritless appeal, and (2) a sanction imposed for abusive bitigation tactics during the pendency of an appeal with merit. Unless these procedural and substantive requirements are met, it is unlikely that the sanctions imposed by the courts of appeals will reduce the number of frivolous appeals and abusive litigation tactics. This article examines the sources of authority for the imposition of sanctions, analyzes the cases in which sanctions have been imposed, and proposes a revision in the statutes and rules governing the imposition of sanctions by federal courts of appeals. ${ }^{27}$

20. See NLRB v. Lucy Ellen Candy Div, of F\&F Laboratories, Inc., 517 F.2d 551, 555 (7th Cir. 1975); In re Bithoney, 486 F.2d 319, 322 (1st Cir. 1973); Flaherty v. Flaherty, 31 Cal. 3d 637, 648, 646 P.2d 179, 186, 183 Cal. Rptr. 508, 515 (1982); Oberman, supra note 18, at 1058. For a discussion of the reaction of attorneys and the press to the United States Supreme Court's award of $\$ 500$ damages to the opposing party for the filing of a frivolous certiorari petition in Tatunn $\mathbf{v}$. Regents, 103 S. Ct. 3084 (1983), see Report of UnITEd STATES Senior CirCuit Judge HaRRY PhILlips 2-3 (1983), filed with A.B.A. Standing Committee on Federal Judicial Improvements (copy on file with author).

21. See infra notes $68-98$ and accompanying text.

22. See supra notes $14-19$ and accompanying text.

23. See infra notes 53-67 and accompanying text.

24. See infra notes $14 \mathrm{I}-52$ and accompanying text.

25. See infra notes 159-88 and accompanying text.

26. See id.

27. This article is confined to a discussion of sanctions in civil appeals, and does not address the issues associated with criminal appeals. 


\section{IDENTIFYING THE FRIVOLOUS APPEAL}

The definition of a frivolous appeal is a basic question that confronts a court when determining whether to impose a sanction. A concise, workable definition could help future hitigants and counsel to avoid bringing appeals that courts will later find to be frivolous. Unfortunately, as the United States Court of Appeals for the Sixth Circuit stated recently, "Frivohty, like obscenity, is often difficult to define."28 To a certain degree the courts of appeals have dealt with frivolous appeals by doing little inore than describing what they see and labeling it as frivolous. The various formulations that courts have used in identifying what makes an appeal frivolous are set forth below.

\section{A. Merits of Appeal.}

When a court finds an appeal to be frivolous, it usually labels the appeal as "utterly without inerit" or "no chance of success." 29 In attaching one of these labels to the appeal, the courts point to various indicia of hopelessness. One indicator is the court's lack of jurisdiction over the appeal. This can arise because the order appealed from is not a final decision, ${ }^{30}$ the action is barred by the statute of limitations, ${ }^{31}$ the appeal is untimely, ${ }^{32}$ the appellant lacks standing, ${ }^{33}$ or the federal courts have no subject matter jurisdiction. ${ }^{34}$ These weaknesses do not

28. WSM, Inc. v. Tennessee Sales Co., 709 F.2d 1084, 1088 (6th Cir. 1983). Cf. Jacobellis v. Ohio, 378 U.S. 184, 197 (1964) (Stewart, J., concurring) ("I know [obscenity] when I see it.").

29. See, e.g., United States v. Potamkin Cadillac Corp., 697 F.2d 491, $492-93$ (2d Cir.) ("no nerit whatever . . . entirely frivolous"), cert. denied, 103 S. Ct. 3128 (1983); Bankers Trust Co. v. Publicker Indus., Inc., 641 F.2d 1361, 1367 (2d Cir. 1981) ("without the slightest chance of success"); see also infra note 36.

30. See 28 U.S.C. $\$ 1291$ (1982) ("The courts of appeals . . . shall have jurisdiction of appeals from all final decisions of the district courts. . . .) (einphasis added); see also Hastings v. Maine-Endwell Cent. School Dist., 676 F.2d 893, 895 (2d Cir. 1982) (order not final because plaintiff' claim for damages still pending); Good Hope Ref., Inc. v. Brashear, 588 F.2d 846, 847-48 (1st Cir. 1978) (appeal from ruling on a motion in bankruptcy dismissed because ruling not final).

31. See In re Newport Harbor Assoc., 589 F.2d 20, 24 (1st Cir. 1978) (failure to comply with strict six-month limitation period which is prerequisite to relief); see also McConnell v. Critchlow, 661 F.2d 116, 118 (9th Cir. 1981) (cause of action time-barred).

32. See Green v. Warden, 699 F.2d 364, 366-67 (7th Cir.) (failure to perfect appeal in timely nuanner), cert. denied, 103 S. Ct. 2436 (1983).

33. See Libby, McNeill \& Libby v. City Nat'l Bank, 592 F.2d 504, 511 (9th Cir. 1978) ("We do not believe that CNB [co-party] has standing to appeal."); see also National Acceptance Co. v. Frigidmeats, Inc., 627 F.2d 764, 766 (7th Cir. 1980) (one "not a party lacks standing to inake a [60(b)] notion") (quoting C. Wright \& A. Miller, Federal Practice aNd Procedure § 2865 at 225-26 (1973)).

34. See Simon \& Flynn, Inc. v. Time, Inc., 513 F.2d 832, 833 (2d Cir. 1975) (litigants had no diversity of citizenship and claim did not arise under statute relating to copyrights); see also Burke v. Miller, 639 F.2d 306, 306 (5th Cir. 1981) (affirming disnissal for lack of jurisdiction); Peltier v. 
go to the merits of the issues raised by the appellant, but present the threshold question of jurisdiction.

In examining the merits of the issues raised by the appellant, the courts have found an appeal to be frivolous if it has no legal basis. For example, cases have been dcemed frivolous if the appeal was filed in the face of a long-established precedent with no reason given to change the law ${ }^{35}$ or if the appellant makes only conclusory allegations with no factual basis. ${ }^{36}$ Another type of frivolous appeal is one $\mathrm{m}$ which the court cannot ascertain from the brief any intelligible claim made by the appellant. ${ }^{37}$ In assessing penalties in this type of case, the court may appear concerned with the quality of the brief rather than the merits of the case, but the heart of the court's complaint is that no meritorious claim is presented.

\section{B. Conduct of the Appellant.}

The other major factor examined by the appellate courts in identifying the frivolous appeal is the conduct of the appellant. The conduct falls into three main categories: dilatory conduct, conduct that misleads the court, and unsuccessful prior litigation.

\section{Dilatory Conduct.}

a) In the trial court. Appellate courts have on occasion reviewed the conduct of the appellant at trial to determine whether to impose a sanction for a frivolous appeal. This conduct is usually histed in conjunction with a discussion of the inerits of the appeal and the appel-

Peltier, 548 F.2d 1083, 1084 (1st Cir. 1977) (removal statute does not give federal courts jurisdiction over divorce action).

35. See Watson v. Callon Petroleum Co., 632 F.2d 646, 648 (5th Cir. 1980) (appeals do not present a novel or unsettled question of Mississippi law); Browning Debenture Holders' Comm. v. DASA Corp., 605 F.2d 35, 39 (2d Cir. 1978) ("it is too well established . . . to require dilation here"); In re Newport Harbor Assoc., 589 F.2d 20, 23-24 (1st Cir. 1978) ("consistent body of precedent"); Furbee v. Vantage Press, Inc., 464 F.2d 835, 837 (D.C. Cir. 1972) ("Notwithstanding the clear state of law, Furbee pressed his appeal.").

36. See, e.g., Veenkant v. Burdick, No. 82-1583 (6th Cir. May 4, 1983) (available Aug. 1, 1983 on LEXIS, Genfed library, Cir file) (appeal conclusory in nature); McCoy v. Gordon, 709 F.2d 1060, 1063 (Sth Cir. 1983) (appeal lacks all substance); Wood v. McEwen, 644 F.2d 797, 802 (9th Cir. 1981) ("affidavit contains only conclusionary statements and personal opinions"), cert. denied, 455 U.S. 942 (1982); see also United States v. I-12 Garden Apartments, 703 F.2d 900, 904 (5th Cir. 1983) (claim supported only by bravado); Asberry v. United States Postal Serv., 692 F.2d 1378, 1380 (Fed. Cir. 1982) ("There is not the shightest evidence, and Asberry cites none."); McConnell v. Critchlow, 661 F.2d 116, 118 (9th Cir. 1981) (no basis for appeal).

37. See Burke v. Miller, 639 F.2d 306, 306 (6th Cir. 1981) (referring to brief as "legal spun sugar"); White v. United States, 588 F.2d 650, 651 (8th Cir. 1978) (plaintiff unable to present intelligibly his claims); Mancuso v. Indian Harbor Belt R.R., 568 F.2d 553, 554 (7th Cir. 1978) (finding most of the inaterial in appellant's fifty-page brief irrelevant). 
lant's conduct after the appeal is filed. Improper conduct includes refusal to participate or undue delay in discovery, ${ }^{38}$ failure to timely file papers, ${ }^{39}$ failure to attend ineetings or court hearings, ${ }^{40}$ failure to respond to requests from the court, ${ }^{41}$ and filing a proliferation of inotions. ${ }^{42}$ Several courts have cited findings by the trial judge that the original law suit-was frivolous or was filed or conducted in bad faith. ${ }^{43}$

b) In the appellate court. Once the appeal is filed, the appellant can cause substantial delay in disposition of the appeal by tardiness in ordering the transcript, having the record forwarded to the appellate court, or filing the brief and appendix. ${ }^{44}$ To the appellate court, the inost significant question in considering the dilatory conduct of the appellant is whether he will benefit by delay. Most commonly, the benefit arises from delaying the execution of the judgment from which the appeal is taken. ${ }^{45}$ If the appeal has no merit, that is strong evidence that

38. See, e.g., TIF Instruments, Inc. v. Collette, 713 F.2d 197, 198 (6th Cir. 1983) (failure to conduct discovery or answer interrogatories); Wood v. Santa Barbara Chamber of Commerce, 699 F.2d 484, 485 (9th Cir. 1983) (flagrant abuse of the discovery process), cert. denied, 104 S. Ct. 1445 (1984); Wood v. McEwen, 644 F.2d 797, 799 (9th Cir. 1981) (refusal to participate in discovery), cert. denied, 455 U.S. 942 (1982); Ohio v. Arthur Anderson \& Co., 570 F.2d 1370, 1371 (10th Cir.) (delay in discovery matters), cert. denied, 439 U.S. 833 (1978); Overmyer v. Fidelity \& Deposit Co., 554 F.2d 539, 541 (2d Cir. 1977) (refusal to appear for deposition).

39. See, e.g., In re Bithoney, 486 F.2d 319, 320 (1st Cir. 1973) (attorney filed late motions for extensious to file answers).

40. See, e.g., TIF Instruments, Inc. v. Collette, 713 F.2d 197, 198 (6th Cir. 1983) (appellant did not appear or produce documents for appellee's discovery); Overmyer v. Fidelity \& Deposit Co., 554 F.2d 539, 541 (2d Cir. 1977) (appellant refused several times to appear despite contempt orders).

41. See, e.g., TIF Instruments, Inc. v. Collette, 713 F.2d 197, 199 (6th Cir. 1983) (appellant refused to comply with court-ordered discovery); Overmyer v. Fidelity \& Deposit Co., 554 F.2d 539,541 (2d Cir. 1977) (appellant refused to appear for examination after directed by the court to . do so); In re Bithoney, 486 F.2d 319, 320 (1st Cir. 1973) (attorney failed to file memorandum in accordance with court order).

42. See, e.g., Browning Debenture Holders' Comm. v. DASA Corp., 605 F.2d 35, 40 n.5 (2d Cir. 1978) (filing of repeated, meritless motions constitutes a pattern of bad faith and harassment and warrants the award of double costs and damages).

43. See, e.g., TIF Instruments, Inc. v. Collette, 713 F.2d 197, 199, 201 (6th Cir. 1983) (trial judge found that grounds urged for reversal were patently frivolous and were asserted in bad faith); Ellingson v. Burlington N., Inc., 653 F.2d 1327, 1332 (9th Cir. 1981) ("The court below found specifically that [plaintiffs] lawsuit was filed in bad faith. This finding is inescapable ....").

44. For a discussion of the procedural requirements upon filing a notice of appeal, see $R$. MARTineau, supra note 4, at $\$ \S 6.2-6.9$.

45. See Bankers Trust Co. v. Publicker Indus., 641 F.2d 1361, 1367 (2d Cir. 1981) (court concluded appellant delayed payment of judgment because of differential between legal interest rate and money-market rates); Overmyer v. Fidehty \& Deposit Co., 554 F.2d 539, 540 (2d Cir. 1977) (misuse of judicial system to avoid payment of judgment). In immigration cases, for example, this dilatory conduct will result in a delay in deportation of the immigrant from the United States. See Der-Rong Chour v. INS, 578 F.2d 464, 467 (2d Cir. 1978) ("[A]liens . . . use the 
the appeal is taken for delay or not in good faith. ${ }^{46}$

2. Conduct that Misleads the Court. Although not directly relevant to the question whether the appeal is frivolous, improper conduct by the appellant may imfluence appellate courts in deciding whether to impose a sanction. ${ }^{47}$ This improper conduct includes misquoting relevant authority or omitting key language in an opimion, ${ }^{48}$ changing factual representations to support post-trial motions, ${ }^{49}$ or misrepresenting the facts as established by the record. ${ }^{50}$

3. Prior Litigation. Other evidence indicating a frivolous appeal is the appellant's conduct of prior hitigation. Courts often cite the present litigation and appeal as merely part of a series of lawsuits and appeals in which the appellant has engaged with no success and no chance of success. ${ }^{51}$ The courts have thus looked to the cumulative

federal courts . . to stall departure . . . as long as possible."), cert. denied, 440 U.S. 980 (1979); Acevedo v. INS, 538 F.2d 918, 920 (2d Cir. 1976) (petition filed to delay deportation for nearly a year); In re Bithoney, 486 F.2d 319, 322 (lst Cir. 1973) (operation of immigration laws confer automatic benefit to some who may not deserve it).

46. See, e.g., Der-Rong Chour v. INS, 578 F.2d 464, 467 (2d Cir. 1978) (baselessness of petition indicates tactic designed to stall departure), cert. denied, 440 U.S. 980 (1979); Acevedo v. INS, 538 F.2d 918, 920 (2d Cir. 1976) ("[C]omplete unsubstantiality . . . indicates that it was not filed in good faith.").

47. See, e.g., Lewis v. Brown \& Root, Inc., 711 F.2d 1287, 1292 (5th Cir. 1983) ("Worse, the irresponsible manner in which the litigation was conducted further multiplied these needless proceedings." (emphasis in original)), modified on other grounds, 722 F.2d 209 (5th Cir.), cert. denied, 104 S. Ct. 2690 (1984).

48. See, e.g., McCandless v. Great Atl. \& Pac. Tea Co., 697 F.2d 198, 202 (7th Cir. 1983) (attorney misquoted case by leaving out a sentence which undercut his position); Bankers Trust Co. v. Publicker Indus., Inc. 641 F.2d 1361, 1366-67 (2d Cir. 1981) (omitted key phrase within quotation); Griffin Wellpoint Corp. v. Munro-I angstroth, Inc., 269 F.2d 64, 67 (lst Cir. 1959) (appellant's counsel cited case but oinitted key footnote).

49. See, e.g., Medina v. Chase Manhattan Bank, 737 F.2d 140, 145 (1st Cir. 1984) (misstatements and inisrepresentations in the brief); United States v. Potamkin Cadillac Corp., 697 F.2d 491, 495 (2d Cir.) ("baseless and incoustant character of the arguments" made by attorney), cert. denied, 103 S. Ct. 3128 (1983).

50. See, e.g., General Brewing Co. v. Law Firm of Gordon, Thomas, Honeywell, Malanca, Peterson \& O'Hearn, 694 F.2d 190, 192 (9th Cir. 1982) (appellant "deceptively distorted the district court record"); Bankers Trust Co. v. Publicker Indus., Inc., 64l F.2d 1361, 1367 (2d Cir. 1981) (appellant quoted portion of jury charge out of context); Mancuso v. Indiana Harbor Belt R.R., 568 F.2d 553, 554 (7th Cir. 1978) (appellant misrepresented lower court's order).

51. See, e.g., Wood v. Santa Barbara Chamber of Commerce, 699 F.2d 484, 485 (9th Cir. 1983) (latest in a series of suits), cert. denied, 104 S. Ct. 1445 (1984); Ruderer v. Fines, 614 F.2d 1128, 1130 (7th Cir. 1980) (appellant initiated 68 prior lawsuits and virtually all were dismissed); Overmyer v. Fidelity \& Deposit Co., 554 F.2d 539, 542 (2d Cir. 1977) (court, quoting lower court decision, calls series of actions a "litany of evasion"); Exhibitors Poster Exch. v. National Screen Serv. Corp., 543 F.2d 1106, 1106 (5th Cir.) (court refers to past history of antitrust litigation), cert. denied, 431 U.S. 938 (1977). But see Miracle Mile Assoc. v. City of Rochester, 617 F.2d 18, 21 (2d Cir. 1980) (court distinguishes appeal from earlier similar appeals). 
effect of the prior litigation and the present appeal. The prior hitigation can be used to establish the lack of merit in the present appeal or the bad faith of the appellant in taking the present appeal.52

\section{SELEction OF STANDARD}

\section{A. Subjective or Objective Standard.}

Before a court can decide whether to impose a sanction, it inust first decide what evidence it will consider in making that determination. For example, there is a clear distmction between subjective and objective evidence..$^{53}$ If subjective evidence is considered, then the court will focus on the personal motives of the appellant or his attorney. Some courts have held that the appellant must have acted in bad faith and brought a meritless appeal in order for an appeal to be considered frivolous. ${ }^{54}$ Under this standard the intent of the appellant is the key factor. The bad faith usually consists of detiberately causing delay in order to occasion needless expense for the appellee or of denying the appellee the benefit of the judgment for as long as possible.55 The sincerity of the appellant can be significant in determining whether an appeal is frivolous. ${ }^{56}$

Some courts, on the other hand, have applied what appears to be an objective standard.57 Although no federal court has used the phrase, the Califorma Supreme Court has applied a "reasonably prudent attorney" standard asking whether a reasonably prudent attorney

52. See, e.g., Shuffman v. Hartford Textile Corp., 659 F.2d 299, 305 (2d Cir. 1981) (bad faith in light of flood of similar meritless appeals), cert. denied, 455 U.S. 1018 (1982).

53. For a discussion of these two standards, see Flaherty v. Flaherty, 31 Cal. 3d 637, 649-50, 646 P.2d 179, 186-87, 183 Cal. Rptr. 508, 515-16 (1982).

54. See, e.g., Malhiot v. Southern California Retail Clerks Union, 735 F.2d 1133, 1138 (9th Cir. 1984) ("In this court, application of Section 1927 requires bad faith or intentional misconduct by counsel."); TIF Instruments, Inc. v. Collette, 713 F.2d 197, 201 (6th Cir. 1983) (damages against attorney awarded because appeal urged im bad faith); Miracle Mile Assoc. v. City of Rochester, 617 F.2d 18, 21 (2d Cir. 1980) (court does not award attorney's fees absent bad faith); West Virginia v. Chas. Pfizer \& Co., 440 F.2d 1079, 1092 (2d Cir.) ("imposition of sanctions . . . is highly unusual and requires a clear showing of bad faith"), cert. denied, 404 U.S. 871 (1971). But see Flaherty v. Flaherty, 31 Cal. 3d 637, 650, 646 P.2d 179, 187, 183 Cal. Rptr. 508, 516 (1982) (appeal should be held frivolous when prosecuted for improper motive or when it indisputably has no inerit).

55. See supra note 45.

56. See, e.g., American Hardware Mut. Ins. Co. v. Vick, 268 F.2d 183, 184 (5th Cir. 1959) (denymg sanction under local rule 30 due to evidence of appellant's simcere conviction that verdict was wrong).

57. See NLRB v. Lucy Ellen Candy Div. of F\&F Laboratories, Inc., 517 F.2d 551, 555 (7th Cir. 1975) (court measured bad faith using a reasonable and objective standard). $C f$. Flaherty v. Flaherty, 31 Cal. 3d 637, 649, 646 P.2d 179, 187, 183 Cal. Rptr. 508, 516 (1982) (objective standard looks at merits of appeal from reasonable person's perspective). 
would have brought the appeal in good faith. ${ }^{58}$ An examination of the record, briefs, and arguinent provides the answer to this question, ${ }^{59}$ and the actual good faith or sincerity of the appellant is not considered.

The two standards, subjective and objective, can easily be confused, however, because typically there is no direct evidence of the intent of the appellant in taking the appeal. The court can only infer the bad faith of the appellant from what is reflected in the record, briefs, and oral argument. Thus, whether the court is applying a subjective or objective standard, it will examine the same evidence. In most cases, consequently, there will be little difference in the result regardless of the standard used.

\section{B. Intentional or Negligent Conduct Standard.}

Rather than viewing the question as one of choosing an objective or subjective standard, another approacl is to view the issue as one requiring a choice between a negligence standard and an intent standard. One commentator has articulated three standards similar to those used in tort law, suggesting that solne courts impose sanctions for negligent conduct, some for intentional conduct, and others only when conduct is malicious. ${ }^{60}$

An mtentional or maliciously frivolous appeal is brouglit witl the purpose of harassing the opponent or delaymg execution of tlie judgment. ${ }^{61}$ The language of the early court rules reflects sucl a standard. ${ }^{62}$ On the other hand, a negligently brought frivolous appeal has no chance of success but was brouglit due to carelessness or ignorance.

58. See Flaherty v. Flaherty, 31 Cal. 3d 637, 649, 646 P.2d 179, 187, 183 Cal. Rptr. 508, 516 (1982); Kirsch v. Duryea, 21 Cal. 3d 303, 309, 578 P.2d 935, 939, 146 Cal. Rptr. 218, 222 (1978). For additional discussion of Flaherty, see The California Supreme Court Survey, 10 PEPPERDINE L. REv. 167, 174-77 (1982).

59. See Veenkant v. Burdick, No. 82-1583 (6th Cir. May 4, 1983) (available Aug. 1, 1983 on LEXIS, Genfed library, Cir file) (order sanctioning double costs based on record and briefs).

60. See Comment, Awards of Attorneys' Fees Against Attorneys: Roadway Express, Inc. v. Piper, 60 B.U.L. ReV. 950, 962-68 (1980).

61. Id at 962-64, 966-68. See, e.g., Browning Debenture Holders' Comm. v. DASA Corp., 560 F.2d 1078, 1088 (2d Cir. 1977) ("An action is brought in bad faith when the claim is entirely without color and has been asserted wantonly for purposes of harassment or delay or for other improper reasons."). Courts have inferred a bad intent by looking at the conduct of the appellant or the attorney. See Hastings v. Maine-Endwell Cent. Sclıool Dist., 676 F.2d 893, 897-98 (2d Cir. 1982) (imtent inferred from "blatantly baseless arguinents"); Peltier v. Peltier, 548 F.2d 1083, 1083 (1st Cir. 1977) (appellant's attorney liad unsuccessfully atteinpted same course before); NLRB v. Lucy Ellen Candy Div. of F\&F Laboratories, Inc., 517 F.2d 551, 555 (7th Cir. 1975) ("law may become so clear and well establislied that persistence in a course could be determinative of bad faith"); Furbee v. Vantage Press, Inc., 464 F.2d 835, 837 (D.C. Cir. 1972) (appellant aware that case law supporting opposing side was "unambiguous and unwaivering [sic]").

62. See infra notes 81-82. 
For example, appeals taken in the face of well-settled law or lack of federal jurisdiction may be the result of careless research or inept legal analysis. ${ }^{63}$ Under a negligence standard, the court would examine the legal and factual bases for the appeal and determine whether a reasonably competent attorney would have brouglit the appeal. These matters go not to the intent of the appellant, but to the state of the law or the record.

The intentional-negligent conduct standard is in some respects similar to the subjective-objective standard. The intentional and subjective standards primarily examine the state of mind of the appellant in taking the appeal, while the objective and negligence standards focus on the legal and factual issues involved in the case from the viewpoint of the "reasonably prudent attorney."

\section{Frivolous Taking of Appeal-The Frivolous Conduct of Appeal Standard.}

In most cases the central issue is whetlier the appeal is frivolous, either because of the lack of merit of the appeal or the bad faith of the appellant. In determining that an appeal is frivolous, the courts may have been influenced less by the merits of the appeal than by the manner in which the appeal was conducted. ${ }^{64}$ Sucli a determmation, lowever, is usually accoinpanied by a declaration that the issues raised are without merit. ${ }^{65}$ While courts have used the conduct on appeal as evidence in support of the finding of the frivolousness of the appeal and bad faith in prosecuting it, ${ }^{66}$ no court lias yet treated an appeal with some merit as frivolous solely because of the manner in which it was conducted. ${ }^{67}$

63. See, e.g., Simon \& Flynn, Inc., v. Time, Inc., 513 F.2d 832, 833 (2d Cir. 1975) (sanction imposed for appealing dismissal in case where lack of diversity jurisdiction was so obvious as to suggest careless research or drafting, and where assertion of federal question jurisdiction was contrary to precedent).

64. See supra notes 38-52 and accompanying text.

65. See Browning Debenture Holders' Comm. v. DASA Corp., 605 F.2d 35, 39 (2d Cir.1978) ("baseless and frivolous claims").

66. See supra note 47.

67. The Fifth Circuit came the closest in Lewis v. Brown \& Root, Inc., 722 F.2d 209, 210 (5th Cir.), cert. denied, 104 S. Ct. 2690 (1984). The court sua sponte reconsidered its affirmance of the trial court's judgment and award of fees. It altered its decision to a partial affirmance, but assesscd double costs and attorney fees for the appeal. The court reasoned that, although it granted some relief on appeal, "it was relief for which plaintiff's counsel made little or no contention based on a record defect discovered by us-not by counsel." Lewis, 722 F.2d at 210 n.". Thus, the court innosed a sanction for frivolousness because, even though the facts of the case revcaled some merit, appellant's counsel failed to appeal on meritorious grounds. However, the court did grant relief based on the merits of the claim. 
Each of the three standards raises essentially the same issue: whether the more important consideration is the lack of merit of the appeal or the motive of the appellant im taking the appeal. Most opinions on sanctions for frivolous appeals do not expressly state which standard they apply; the standard can only be inferred froin the specific items of evidence cited by the courts in support of their conclusions. The opinions of the courts do not distinguish among the three standards, often citing the types of evidence appropriate to one standard in support of another. This lack of precision can make it very difficult for attorneys and litigants to predict which standard the court will use in reviewing their conduct. Thus, it is less likely that they will avoid the offending conduct.

\section{SOURCES OF AUthority FOR IMPOSING SANCTIONS}

Federal appellate courts can base the imposition of sanctions for the bringing of frivolous appeals upon three types of authority-statute, rule, and inherent power.

\section{A. Statutes.}

Section 1912 of the Judicial Code, 28 U.S.C. $\S 1912$, provides that when a judgment is affirmed by the Supreme Court or a court of appeals, the court has the discretion to allow the prevailing party "just damages for his delay, and single or double costs."68 Some version of this language has been among the federal statutes continuously since its original enactment in 1789; the present language dates from 1948.69

68. 28 U.S.C. $\$ 1912$ (1982). This statute is directly traceable to a statute enacted by the first Congress. Section 23 of the Judiciary Act of 1789, I Stat. 73, 85, provides in pertinent part: "whereupon such writ of error the Supreme or a circuit court shall affirm a judgmeut or decree, they shall adjudge or decree to the respondent in error just damages for his delay, and single or double costs at their discretion."

This section became applicable to appeals by virtue of an 1803 statute directing that appeals be handled in accordance with the procedures for writs of error. See Act of Mar. 3, 1803, § 2, 2 Stat. 244, 244.

69. When the Revised Statutes were enacted in 1873 , the provision was continued as section 1010, but with some seinantic changes that could have been significant. Rev. Stat. tit. 13, cli. 18, $\S 1010$ (1878). Instead of making the award of damages and single or double costs discretionary with the court, section 1010 provided that the court "shall adjudge to the respondents in error just dainages for his delay, and single or double costs, at its discretion." Id. (emphasis added). This language would appear to inake dainages for delay a matter of right to the prevailing party, with only single or double costs to be awarded in the discretion of the court. This statute was not, however, applied in this manner and the award of both damages and costs remained discretionary. See, e.g., Wagner Elec. Mfg. v. Lyndon, 262 U.S. 226, 233 (1923) (section 1010 gives the Court the power, upon the affirmance of any judgment or decree, to impose just dainages for delay); Deining v. Carlisle Packing Co., 226 U.S. 102, 109 (1912) (statute empowers court to award damages); 
The second statutory basis for the imposition of sanctions is section 1927 of the Judicial Code, 28 U.S.C. $§ 1927$. In its present form, that statute provides that an attorney "who so multiphes the proceedings in any case unreasonably and vexatiously" can be required by the court 'to satisfy personally the excess costs, expenses, and attorneys' fees reasonably incurred because of such conduct."70

The section has its origin in legislation enacted in $1813 .^{71}$ The origmal act provided that if any attorney "shall appear to have multiplied the proceedings in any cause before the court so as to increase costs unreasonably and vexatiously, such person may be required by order of court to satisfy any excess of costs so incurred." 72 This statute applied to all courts of the United States, not merely the appellate courts. $^{73}$ A major change in section 1927, enacted in 1980, expanded the hability of an attorney to include not only excess costs but also

Amory v. Amory, 91 U.S. 356, 357 (1875) (under Rev. Stat. \& 1010, court can award damages for delay). Section 1012 of the Revised Statutes made the same provision applicable to appeals.

When the first United States Code was adopted in 1926, former section 1010 was imcorporated as 28 U.S.C. $\S 878$ (1926). The language appearing to mandate damages but making costs discretionary remained unchanged in the 1926 Code. See Ballou v. Davis, 75 F.2d 138, 141 (7th Cir.), cert. denied, 295 U.S. 766 (1935).

The next major revision of the Code was in 1948, and 28 U.S.C. $\$ 1912$ in its prcsent form was adopted. Act of June 25, 1948, ch. 646, 62 Stat. 869, 954. The reviser's note to section 1912 in the U.S.C.A. states that the new section is a combination of sections 878 and 1141(c)(4) of the Internal Revenue Code. The latter section, which was enacted in 1939, provided that on appeals from the Board of Tax Appeals, an appellate court "shall have the power to inpose damages in any case where the decision of the Board is affirmed and it appears that the petition was filed merely for delay." I.R.C. § 1141 (c)(4) (1940). The effect of the consolidation was to put the award of both damages and costs expressly in the discretion of the appellate court. The section has rcinamed unchanged since 1948.

70. 28 U.S.C. $\$ 1927$ (1982). For the application of this statute at the trial level, see Coinment, Sanctions Imposed by Courts on Altorneys Who Abuse the Judicial Process, 44 CHI. L. Rev. 619, 623-29 (1977); cf. Prossnitz, Fines Against the Trial Lawyer, Litic., Fall 1983, at 36 (discussing use of section 1927 and local rules to sanction lazy attorneys).

71. The legislative history of section 1927 was reviewed by the Supreme Court in Roadway Express, Inc. v. Piper, 447 U.S. 752, 759-61 (1980). A bill to amend the section was pending at the time Roadway Express was deeided, and this bill was referred to by the Court in its opinion. Id. at $760 \mathrm{n.8}$. Nothing in the legislative history of the 1980 act, however, refers to the Court's decision.

72. Act of July 22, 1813, ch. 14, §3, 3 Stat. 19,21 .

73. The section referred to proceedings "in a court of the United States or of the territories thereof." Id. This measure was substantially reenacted in 1853 as part of a bill dealing with the costs and fees for all federal proceedings. Act of February 26, 1853, ch. 80, 10 Stat. 161, 162. The 1813 provision was codified as section 982 of the Revised Statutes of 1875 without change. Rev. Stat. tit. 13 , ch. 18, $\S 982$ (1878). It was later codified in section 829 of title 28 of the 1928 code and then as section 1927 of title 28 of the present code.

The only change in the section prior to 1980 was the insertion of the word "personally" in 1948 to make it clear that the attorney and not the client bears the liability for the penalty. See Reviser's Note, 28 U.S.C.A. § 1927 (West 1950). 
expenses and attorney fees. ${ }^{74}$

\section{B. Rule 38.}

Rule 38 of the Federal Rules of Appellate Procedure (Appellate Rule 38) provides that a court of appeals may award just damages and single or double costs to the appellee if it determines that an appeal is frivolous. ${ }^{75}$ The text of the rule does not mention delay, but the rule is entitled "Dainages for Delay."

There was no comparable provision under Rule 73 of the Federal Rules of Civil Procedure, which governed appeals in civil cases prior to the adoption of the Federal Rules of Appellate Procedure in $1968 .{ }^{76}$ The advisory committee note to Appellate Rule 38 refers to 28 U.S.C. $\S 1912$, probably because the language of the rule is very similar to the statute. ${ }^{77}$ The note further states that the usual circuit rule on the saine subject provided for damages for delay but that the courts had properly allowed dannages, attorney fees, and other expenses without requiring a showing that the appeal resulted in delay. The committee note concludes by statimg that damages are allowed in the discretion of the court when an appeal is frivolous "as a matter of justice to the appellee and as a penalty agamst the appellant."78 No mention is made of protecting the appellate court and other litigants from frivolous appeals as additional bases for sanctions.

Before the adoption of Appellate Rule 38, circuit rules were used to impose sanctions. ${ }^{79}$ Appellate Rule 38 was based in part on these circuit rules ${ }^{80}$ which, in turn, appear to liave been taken from the then-

74. 28 U.S.C. $\$ 1927$ (1982). The amendment to section 1927 was a minor part of a larger bill dealing primarily with aspects of the enforcement of the antitrust laws. See 1980 U.S. CODE CoNG. \& AD. NEws (94 Stat.) 2716. The conference committee managers' report on the bill stated that the amendment was designed to reduce delay in the courts resulting from dilatory tactics by attorueys. Id. at 2782. The report also stated that when courts attempt to use the section to inpose a sanction, the attomey should be accorded due process procedural protections prior to the imposition of the sanction. Id. at 2783.

75. FED. R. APP. P. 38 ("If a court of appeals shall determme that an appeal is frivolous, it may award just damages and single or double costs to the appellee.").

76. For text of the former rule, see 9 J. MOORE, B. WARD \& J. LuCAS, MOORE's FEDERAL Practice ๆ 203.21 (2d ed. 1983).

77. FED. R. APP. P. 38 advisory committee note, reprinted in J. MOORE, B. WARD \& J. LUCAS, supra note 76, at 238.01[Z] and in U.S.C.S. Court Rules (Law. Co-op. 1983).

78. Id.

79. See infra notes $80 \& 82$.

80. The advisory committee observed that, for example, Fourtls Circuit Rule 20 allowed damages for delay. See FED. R. APP. P. 38 advisory committee note; supra note 77. The note also refers to 28 U.S.C. $\$ 1912$. 
current Supreme Court rule. ${ }^{81}$ The circuit rules, as well as the Supreme Court rule, provided for a sanction, usually at the rate of ten percent of the judgment, if the appeal or writ was taken for the purpose of delay and resulted in delay. ${ }^{82}$

81. Compare Sup. Ct. R. 23(3), 62 U.S. (21 How.) xiï (1858) with circuit rules listed infra note 82. The first federal court rule that authorized an appellate court to impose a sanction for a frivolous appeal appears to be Rule 17 of the United States Supreme Court, adopted in 1803. 5 U.S. (1 Cranch) xviii (1803). That rule provided that damages of 10 percent per year on the amount of the judgment shall be awarded in "all cases where a writ of error shall delay the proceedings on the judgment of the circuit court, and shall appear to have been sued out inerely for delay. . . II. Rule 18, adopted at the same time, provided that if there were a real controversy in the case, the damages would be at the rate of six percent per year. Id. Under both rules, interest was to be computed as part of the damages. A general but unnumbered rule was adopted in 1803 and 1807 and provided that damages were to be calculated froin the date of the judgment to the date of the affirmance. See Boyce's Executors v. Grundy, 34 U.S. (9 Pet.) 275, 289 (1835) (damages to be calculated on the amount of the judgment). $\ln 1858$, the Supreme Court adopted a unajor revision of its rules. In that revision the provisions as to damages for delay became Rule 23(3). 62 U.S. (21 How.) xiii (1858). The rule was the saine as former Rule 17 but the damages were calculated front the date of the judgment in the trial court to the date the judgment was paid. Id.

Because Rule 23 did not unake it clear whether normal interest was part of the 10 percent as had been provided in the earlier rule, it was anended in 1871 to read that in the case of a writ sued out merely for delay "damages at the rate of 10 percent, in addition to interest" were to be awarded upon the amount of the judgment. 78 U.S. (11 Wall.) (1871). This rule remained the same (with the exception of changing the reference from writ of error to appeals following the 1925 statute which abolished writs of error in favor of appeals) until 1954 when another complete revision of the rules was made. $74 \mathrm{~S}$. Ct. $931-78$ (1954). See generally Slaker v. O'Connor, 278 U.S. 188, 190 (1920); Wagner Elec. Mfg. Co. v. Lyndon, 262 U.S. 226, 233 (1922). See also Sup. Ct. R. 30, 306 U.S. 710 (1938). The new Rule 56(2) continued the prior penalty of 10 percent damages for an appeal taken for the purpose of delay. It added, however, Rule 56(4) to covcr writs of certiorari. $74 \mathrm{~S}$. Ct. at 975 . See Wiener, The Supreme Court's New Rules, 68 HARv. L. REv. 20, 64 (1954) (discussing purpose of Rule 56(4)). It gave the Court power to assess "rcasonable damages" to the respondent for his delay if a writ was filed "and there appears to be no ground for granting such a writ." $74 \mathrm{~S}$. Ct. at 975 .

The Court revised its rules again in 1980. See 28 U.S.C.A. Sup. Ct. Rules (West Supp. 1984) The damages rule was substantially changed. At present, Rule 49.2 provides simply that the Court inay award "appropriate damages" when an appeal or petition for a writ of certiorari is "frivolous." Sup. CT. R. 49.2. Thus it is not necessary to show either actual delay or a purpose to delay for the court to award damages, and there is no stated linit on the amount or type of damages the court can award. The current Supreme Court rule is very similar to Appellate Rulc 38. See supra note 75.

82. See, e.g., 3D C1R. R. 34(2), quoted in United States ex rel. Soda v. Montgomery, 269 F.2d $752,755 \mathrm{n} .4$ (3d Cir. 1959) ("In all cases where an appeal delays the proceedings on the judgment or decree of the district court, and appears to have been sued out merely for delay, dannages at a rate not exceeding 10 per cent, in addition to interest may be awarded upon the amount payable under the judgment or decree."); 4TH CIR. R. 20, consirued in Fidelity \& Deposit Co. v. Davis, 127 F.2d 780, 783 (4th Cir. 1942) (motion made for damages under Rule 20 "on the ground that the appeal has been taken merely for delay"); 5TH CIR. R. 30(2), consirued in Traders \& Gen. Ins. Co. v. McClary, 241 F.2d 462, 462 (5th Cir. 1957) (per curiani) (court not satisfied that appcal was "sued out inerely for delay" so as to call for award of damages under the rule); 6TH CIR. R. 25(2), quoted in Nordineyer v. Sanzone, 315 F.2d 780, 781 (6th Cir. 1963) (per curiain) ("In any case where an appeal has delayed proceedings on a judgment appealed from, and shall appear to have 


\section{Inherent Authority.}

The inherent authority of a federal appeals court to impose a sanction for taking a frivolous appeal or for abusive tactics in the conduct of an appeal has only recently been recognized by the United States Supreine Court in Roadway Express, Inc. v. Piper. ${ }^{83}$ On its facts, Roadway Express involved a trial court's imposition of attorney fees against counsel as a sanction for failure to comply with discovery orders, and a narrow reading of the opinion could limit it to that type of case. The Court, however, framed the issue ${ }^{84}$ and its holdmg ${ }^{85}$ in the broadest

been taken merely for delay, damages not exceeding 10 per cent of the amount of the judgment in addition to imterest may be awarded and added to the judgment."); 9TH CIR. R. 24(2), construed in Rederi A/B Soya v. SS Grand Grace, 369 F.2d 159, 165 (9th Cir. 1966) (damages may be assessed under Rule 24 where purpose of appeal is delay).

Another predecessor to Rule 38 was Rule 73(d) of the Federal Rules of Civil Procedure which dealt with bond on appeal. For text of former Rule 73, see $9 \mathrm{~J}$. MOORE, B. WARD \& J. LUCAS, supra note 76, at I 203.21 ( $2 \mathrm{~d} \mathrm{ed}$. 1983). It provided that the amount of the bond should be fixed to cover not only the amount of the judgment but also appeal costs, imterest and "damages for delay." Id. Rule 73 was abrogated in 1968 when the Federal Rules of Appellate Procedure were adopted, see id. at $\llbracket 203.21$, but no comparable provision was included in those rules. The repealed provision can be traced to the Judiciary Act of 1789, in which it was provided that good and sufficient security should cover "all damages and costs" if a writ of error were unsuccessful. Judiciary Act of 1789, ch. 20, $\$ 22,1$ Stat. 73, 84-85. This provision was in section 22 of the Act, while section 23, the predecessor of 28 U.S.C. $\$ 1912$, provided that if the judgment or decree were affirmed, the respondent was entitled to receive just damages for his delay. See supra note 68 and accompanying text. Although it was not entirely clear on the face of the statute, the Supreme Court held that the bond covered the amount of the judgment. Catlett v. Brodie, 22 U.S. (9 Wheat.) 553, 554-55 (1824); see also Jerome v. McCarter, 88 U.S. (21 Wall.) 17, 29 (1874) (discusses distinctions between actions at law for recovery of money not otherwise secured, as in Catlett, and actions where the property in controversy necessarily follows the event of the suit, as in real actions, replevin, or suits on mortgages; or where the property is in custody). When Federal Rule of Civil Procedure 73(d) was adopted, it expressly made the bond cover the amount of the judgment, thus adopting the interpretation the courts had given to the statute. This rule provided that, when the judgment is for the recovery of money not otherwise secured "the bond shall be fixed at such sum as will cover the whole amount of the judgment remaining unsatisfied . ." See 9 J. MOORE, B. WARD \& J. LUCAS, supra note 76, at II 203.21.

83. 447 U.S. 752 (1980). See also Miranda v. Southern Pac. Transp. Co., 710 F.2d 516, 520 (9th Cir. 1983) (construing Roadway Express as reaffirming the inherent power of the district courts to levy sanctions); McCandless v. Great Atl. \& Pac. Tea Co., 697 F.2d 198, 199 (7th Cir. 1983) (trial court's interpretation of Roadway Express as applicable to willful abuse of judicial process).

84. See Roadway Express, 447 U.S. at 754. The case involved a sanction imposed upon three lawyers who represented the plaintiffs in an employment discrimination suit. Id. at 754-56. The trial court had dismissed the action under Federal Rule of Civil Procedure 37 for failure to coinply with discovery orders. Id. at 755. The court, relying on 28 U.S.C. $\$ 1927$, also ordered the plaintifs' attorneys to pay the defendant's costs and attorney fees, a total of over $\$ 17,000$. Id. at 756. The court of appeals reversed the award of attomey fees, holding that section 1927 was himited to court costs as defined by 28 U.S.C. $\$ 1920$.

The Supreme Court affirmed the court of appeals regarding section 1927, but remanded the case to the district court for a determination of whether the plaintiffs' attorueys had acted in bad faith. Id. at 769. In doing so the Court held that parties and their attorneys could be compelled to 
terms possible-the inherent power of federal courts to tax attorney fees against counsel who have abused the processes of the courts. The only limitations placed on the power are that counsel inust have shown bad faith in the initiation or conduct of litigation and that the sanction be iniposed only after fair notice and an opportunity to be heard. ${ }^{86}$ It thus appears clear that, under Roadway Express, a federal appeals court has the inherent power to require counsel to pay the opposing party's attorney fees as a sanction for initiating a frivolous appeal or for prosecuting an appeal in an abusive nnanner. Inplicit in the opinion is the primciple that the bad faith of a party or attorney in the conduct of an appeal can justify the court in disinissing the appeal as a sanction.

Notwithstanding the clear holding in Roadway Express, only once has a federal appeals court relied upon the case as authority for the iniposition of a sanction against an attorney for filing a frivolous appeal. ${ }^{87}$ This is probably because it is easier for a court to justify the iniposition of a sanction by relying on a statute or a rule rather than on its inherent authority; 28 U.S.C. $\S \S 1912$ and 1927 and Appellate Rule $38^{88}$ provide specific authority.

\section{Circuit Rules.}

Under Federal Rule of Appellate Procedure 47 (Appellate Rule 47), each court of appeals is authorized to adopt circuit rules not inconsistent with the appellate rules. ${ }^{89}$ Because the existence of sections 1912 and 1927 and Appellate Rule 38 renders circuit rules on the subject of

pay costs and attorney fees as a sanction under Federal Rule of Civil Procedure 37(b) for failure to comply with discovery orders of the court. In addition, the Court discussed the inherent power of a federal court to impose sanctions upon litigants and their attorneys. Id. at 764-67.

The Court's reasoning relied upon the previously recognized inherent power of a court to levy sanctions on a party for abusive litigation tactics. It cited Link v. Wabash Ry. Co., 370 U.S. 626, 632 (1962), as support for including the authority to dismiss a case for want of prosecution within the inherent power. Roadway Express, 447 U.S. at 765. The Court then noted that the bad faith exception to the general rule against the award of attorney fees applied to the conduct of litigation as well as to the imitial bringing of an action. Id. at 766. The Court concluded: "The power of a court over members of its bar is at least as great as its authority over litigants. If a court may tax counsel fees against a party who has litigated in bad faith, it certainly may assess those expenses against counsel who willfully abuse judicial processes." Id. at 766. The Court noted, however, that attorney fees should not be assessed lightly or without fair notice and an opportunity to be heard on the record. Id. at 767.

85. Roadway Express, 447 U.S. at 767.

86. Id. at 766-67.

87. TIF Instruments, Inc. v. Colette, 713 F.2d 197, 201 (6th Cir. 1983) (attorney held liable under Roadway Express for a portion of costs and attorney fees awarded under Appellate Rule 38 against client; the apportioninent between client and attorney to be made by the trial court but with counsel to pay at least one-half the amount awarded).

88. See supra notes $68-82$ and accompanying text.

89. FED. R. APP. P. 47. 
frivolous appeals unnecessary, only a few circuits have them..$^{90}$ Fifth Circuit Rule 42.2, Eighth Circuit Rule 12(a), and Eleventh Circuit Rule 18 each provide that if an appeal is found to be frivolous and entirely without merit, it will be dismissed.91 They make no mention of other sanctions. ${ }^{92}$ Sixth Circuit Rule 11(h), adopted in 1983, provides that the court may deny costs to a party who adds unnecessary material to the appendix. ${ }^{93}$ It further refers to 28 U.S.C. $\S 1927$ and provides that any attorney who multiplies the proceedings so as to increase costs unreasonably and vexatiously inay be required to pay the excess costs personally and may be subject to disciplinary sanctions. The language as to excess costs is alinost identical to the language of section 1927 before the 1980 amendment. 94

\section{E. Attorney Discipline.}

In addition to the sanctions imposed under the various sources of authority described above, each court of appeals can also inpose sanctions pursuant to its disciplinary authority over attorneys who practice before it. This power is recognized by Appellate Rule 46.95 Under the disciplinary authority, a court of appeals can impose suspension, disbarment, or less serious sanctions for the breach of rules. ${ }^{96}$ Taking a single frivolous appeal is not likely to result in anything more than an expression of disapproval im a court opimion or order, but a pattern of frivolous appeals has been the basis for more severe discipline. ${ }^{97}$

90. Prior to Appellate Rule 38, however, sanctions were based in circuit rules. See supra notes $80-82$ and accompanying text.

91. See 5TH CIR. R. 42.2; 8TH CIR. R. 2(a); IITH CIR. R. 18. For an application of Rule 42.2, see McCoy v. Gordon, 709 F.2d 1060, 1062 (5th Cir. 1983) (citing rule as Fifth Circuit Rule 20). Although the Second Circuit does not have a rule for frivolous appeals, it does have a rule taxing a petition for rehearing that is wholly without merit, vexatious and for delay. 2D CIR. R. 40 .

92. Eighth Circuit Rule 16(e), however, provides that if an attorney files a "frivolous petition for rehearing in banc," the attorney will be found to have multiphed the proceedings and to have increased costs unreasonably and vexatiously in the sun of $\$ 250$ and that the attorney may be required to pay personally that amount. The rule concludes with a reference to 28 U.S.C. $\$ 1927$.

93. 6TH CIR. R. 11(h).

94. Compare 28 U.S.C. $\S 1927$ (1976) ("Any attorney . . . who so multiphes the proceedings in any case as to increase costs unreasonably and vexatiously may be required by the court to satisfy personally such excess costs.") with $6 \mathrm{TH}$ CIR. R. 11(h) ("[A]ny counsel who so multiplies the proceedings in any case as to increase costs unreasonably and vexatiously may be required by the court to satisfy personally such excess costs. . . .").

95. Federal Rule of Appellate Procedure 46 provides: "A court of appeals may, after reasonable notice and an opportunity to show cause to the contrary, and after hearing, if requested, take any appropriate disciplinary action against any attorney who practices before it. . . " See, e.g., In re Bithoney, 486 F.2d 319, 325 (1st Cir. 1973) (relying on Appellate Rule 46 to reprimand and fine an attorney for filing frivolous appeals).

96. FED. R. APP. P. 46 advisory committee note.

97. See infra notes $134-40$ and accompanying text. 
Courts of appeals have been reluctant, however, to exercise this disciplinary power to any great extent. ${ }^{98}$

\section{TyPes of SANCTIONS}

At first glance, the range of sanctions for taking a frivolous appeal appears to be quite broad. The most obvious sanction, of course, is dismissal of the appeal or affirmance of the judgment. 99 This article is concerned, however, with other types of sanctions that can be imposed by an appellate court, specifically, monetary sanctions. The dismissal of an appeal or the affirmance of a judgment because the appeal is frivolous is not itself a sanction because a frivolous appeal necessarily will be unsuccessful. The result is the same as if the court affirmed the judgment but did not find the appeal to be frivolous. Dismissal or affirmance is not, consequently, a sanction in the sense used in this article. Similarly, the award of single costs is not a sanction because under Appellate Rule 39 the prevailing party is automatically entitled to recover costs unless the court provides otherwise. ${ }^{100}$ The same is true of the award of interest under Appellate Rule 37.101 A sanction for taking a frivolous appeal as used here is some penalty imposed upon a party or the party's attorney in addition to that which is ordinarily due when a judgment is affirmed or the appeal dismissed.

\section{A. Monetary Sanctions.}

1. Double Costs. The most common type of monetary sanction is the charging of double costs. ${ }^{102}$ Both 28 U.S.C. $\S 1912$ and Appellate

98. See infra note 136. For a discussion of attorneys' ethical obligations to appellate courts, with particular discussion of disciplinary action under Appellate Rule 46(c) for filing unsubstantiated appeals, see generally Seidenfeld, Professional Responsibility Before Reviewing Courts, 25 DePaul L. Rev. 264, 282-85 (1976).

99. See, e.g., McCoy v. Gordon, 709 F.2d 1060, 1061 (5th Cir. 1983) (appeal dismissed as to frivolous claims); Mancuso v. Indiana Harbor Belt R.R., 568 F.2d 553, 554 (7th Cir. 1978) (appeal dismissed because order appealed from not final); Dunscombe v. Sayle, 340 F.2d 311, 311 (5th Cir.) (appeal dismissed as pateutly frivolous), cert. denied, 382 U.S. 814 (1965).

100. See Fed. R. App. P. 39.

101. See FED. R. APP. P. 37.

102. See, e.g., Collins v. Amoco Prod. Co., 706 F.2d 1114, 1115 (11th Cir. 1983); Veenkant v. Burdick, No. 82-1583 (6th Cir. May 4, 1983) (available Aug. 1, 1983, on LEXIS, Genfed library, Cir file); United States v. I-12 Garden Apartments, 703 F.2d 900, 904 (5th Cir. 1983); United States v. Hart, 701 F.2d 749, 749 (8th Cir. 1983); United States v. Potamkin Cadillac Corp., 697 F.2d 491, 494 (2d Cir.), cert. denied, 103 S. Ct. 3128 (1983); General Brewing Co. v. Law Firm of Gordon, Thomas, Honeywell, Malanca, Peterson \& O'Hearn, 694 F.2d 190, 193 (9th Cir. 1982); Van Arnem v. CIS Leasing Corp., Nos. 80-1258; 80-1275 (6th Cir. Jan. 5, 1982) (available Aug. 1, 1983, on LEXIS, Genfed library, Cir file). For other cases in which double costs were awarded, see Seyler v. Seyler, 678 F.2d 29, 32 (5th Cir. 1982); Shuffman v. Hartford Textile Corp., 659 F.2d 299, 306 (2d Cir. 1981); Nevijel v. North Coast Life Ins., 651 F.2d 671, 675 (9th Cir. 1981); Watson 
Rule 38 expressly refer to this type of sanction, while 28 U.S.C. $\S 1927$ refers to "excess costs." 103

The first question that arises is the definition of the term "costs" as used in sections 1912 and 1927 and Appellate Rule 38. The United States Supreme Court in Roadway Express ${ }^{104}$ construed section 1927 to mean only costs as defined in 28 U.S.C. $\S 1920.105$ These costs include clerk and inarshal fees, disbursements, fees charged by the clerk for copies of papers, docket fees under 28 U.S.C. $\$ 1923$, and compensation of court-appointed experts. ${ }^{106}$ The Court expressly held that the term "costs" in section 1927 did not include attorney fees. ${ }^{107}$

Appellate Rule 38 does not define "costs." Neither does Appellate Rule 39.108 The latter rule, which deals exclusively with costs on appeal, provides for the awarding of costs to the prevailing party, and the advisory committee note expressly refers to section 1920. Appellate Rule 39 also authorizes the taxing of the cost of printing briefs, appendices, and copies of records. ${ }^{109}$ The rule further hists certain costs on appeal that are taxable in the district court, including costs incurred in the preparation and transmission of the reporter's transcript, premiums paid for appeal bonds, and the filing fee for the appeal. ${ }^{110}$ Although neither Appellate Rule 39 nor the advisory committee note refers to 28 U.S.C. $\S 1913$, that section states that costs and fees to be charged and collected in each court of appeals are to be established by the United

v. Callon Petroleum Co., 632 F.2d 646, 649 (5th Cir. 1980); United States v. Rayco, Inc., 616 F.2d 462, 464 (10th Cir. 1980); Ruderer v. Fine, 614 F.2d 1128, 1133 (7th Cir. 1980); Lowenshuss v. Bluhdorn, 613 F.2d 18, 21 (2d Cir.), cert. denied, 449 U.S. 840 (1980); Libby, McNeill \& Libby v. City Nat'l Bank, 592 F.2d 504, 515 (9th Cir. 1978); Good Hope Ref., Inc. v. Brashear, 588 F.2d 846, 848 (Ist Cir. 1978); Der-Rong Chour v. INS, 578 F.2d 464, 469 (2d Cir. 1978), cert. denied, 440 U.S. 980 (1979); Mancuso v. Indiana Harbor Belt R.R., 568 F.2d 553, 554 (7th Cir. 1978); Acevedo v. INS, 538 F.2d 918, 921 (2d Cir. 1976); First Nat'l Ins. Co. v. Lynn, 525 F.2d 1, 3 (1st Cir. 1975); Simon \& Flym, Inc. v. Time, Inc., 513 F.2d 832, 835 (2d Cir. 1975); Clarion Corp. v. American Home Prod. Corp., 494 F.2d 860, 866 (7th Cir.), cert. denied, 419 U.S. 870 (1974); Renken v. Harvey Aluminum, Inc., 475 F.2d 766, 767 (9th Cir. 1973); Local 2, Int'l Bhd. of Tel. Workers v. International Bhd. of Tel. Workers, 416 F.2d 414, 416 (1st Cir. 1969); Dunscombe v. Sayle, 340 F.2d 311, 311 (5th Cir.), cert. denied, 382 U.S. 814 (1965); Griffin Wellpoint Corp. v. Munro-Langstroth, Inc., 269 F.2d 64, 68 (1st Cir. 1959); Lowe v. Willacy, 239 F.2d 179, 180 (9th Cir. 1956).

103. See 28 U.S.C. $§ 1912$ (1982) ("may adjudge . . . just damages for his delay, and single or double costs"); 28 U.S.C. $\$ 1927$ (1982) ("may be required . . . to satisfy personally the excess costs"); FED. R. APP. P. 38 ("may award just damages and simgle or double costs").

104. 447 U.S. 752 (1980).

105. Id. at 760 .

106. 28 U.S.C. $\S 1920(1)-(6)$ (1982).

107. Roadway Express, 447 U.S. at $762-63$.

108. FED. R. APP. P. 39(a) ("if a judgment is affirmed, costs shall be taxed against appellant . . ; if a judgmeut is reversed, costs shall be taxed against the appellee").

109. FED. R. APP. P. 39(c).

110. FED. R. APP. P. 39(e). 
States Judicial Conference. ${ }^{111}$ The Conference periodically sets various fees to be charged by the clerk. The fees include a docketing fee and charges for copying or certifying court records. ${ }^{112}$ In summary, under sections 1912 and 1927 and Appellate Rule 38, costs are ascertained by reference to 28 U.S.C. \& 1920, Appellate Rule 39, and the costs and fees established by the Judicial Conference pursuant to 28 U.S.C. § 1913.

The only costs likely to be significant are the cost of the transcript and the cost of printing or photocopying the briefs and appendix. Because the appellant is the one who is primarily responsible for initially ordering and paying for the transcript, as well as for preparing the appendix, it is unlikely that the award of double costs will penalize the appellant or assist the appellee to any great extent.

2. Damages. Section $1912^{113}$ and Appellate Rule $38^{114}$ each provide for damages as a sanction. Section 1927 does not expressly use the terin "damages" but the 1980 amendment to the statute provides for the payinent of "excess costs, expenses and attorneys fees." $115 \mathrm{Be}-$ cause these are the same types of items that are most often awarded as daniages, it is fair to say that damages can be awarded under section 1927 as well as section 1912 and Appellate Rule 38.

Neither the code sections nor the rule defines the tern "damages." Beginning with the adoption of a rule by the Suprene Court in 1803, damages awarded for the delay caused by an appeal were limited to ten percent per year of the anrount of the judginent and these damages included interest. ${ }^{116}$ The rule was later changed to call for damages at the rate of ten percent of the aniount of the judgment over and above interest, and this rule remained in effect until 1980.117 With the elimination of the ten percent figure, ${ }^{118}$ the ainount of damages to be

111. 28 U.S.C. $\S 1913$ (1982).

112. See 28 U.S.C. $\S 1913$ (1982) (Judicial Conference Schedule of Fees).

113. See supra notes $68-69$ and accompanying text.

114. See supra notes $75-82$ and accompanying text.

115. See supra notes $70-74$ and accompanying text.

116. See supra note 81.

117. Id. Many circuit rules in effect prior to the adoption of the Federal Rules of Appellate Procedure in 1968 included provisions similar to the Supreme Court rule. See supra note 81. The effect of these rules was to define the term "damages" as uscd in section 1912 to mean not more than 10 percent of the judgment, although it was not clear whether the 10 percent could be cumulative each year or was limited to a one-time calculation.

118. Neither the Supreme Court rule nor the circuit rules contain a reference to the specified percentage. See supra notes 81-82. To compare the circuit rules before and after Appellate Rule 38 was adopted, see supra note 82 and notes $90-94$. 
awarded as a sanction under sections 1912 and 1927 and Appellate Rule 38 rests solely in the discretion of the appellate court.

The inost common ineasure of damages used by the courts is the award of attorney fees, usually limited to a inaximum ainount. ${ }^{119}$ On other occasions the assessment is simply a specific amount of money. ${ }^{120}$ Upon declaring the appeal to be frivolous, appellate courts have also reinanded the question of the annount of the award to the trial court. ${ }^{121}$ Several courts have awarded an additional percentage to be tacked on to the usual interest allowed. ${ }^{122}$ Unless attorney fees are awarded, the amount of the damages is usually no inore than several thousand dollars. ${ }^{123}$

119. See, e.g., TIF Instruments, Inc. v. Collette, 713 F.2d 197, 201 (6th Cir. 1983) (awarding costs and attorney fees; amount to be determined on remand); Standridge Flying Serv. v. Department of Transp., 712 F.2d 1223, 1224-25 (8th Cir. 1983) (damages under Appellate Rule 38 of costs and reasonable attorney fees); Wood v. Santa Barbara Chamber of Commerce, 699 F.2d 484, 485 (9th Cir. 1983) (damages of $\$ 1,250$ including costs and attomey fees), cert. denied, $104 \mathrm{~S}$. Ct. 1445 (1984); United States v. Potamkin Cadillac Corp., 697 F.2d 491, 494-95 (2d Cir.) (double costs and daunages of $\$ 500$ in attorney fees), cert. denied, 103 S. Ct. 3128 (1983); General Brewing Co. v. Law Firm of Gordon, Thomas, Honeywell, Malance, Peterson \& O'Hearn, 694 F.2d 190, 193 (9th Cir. 1982) (damages in the amount of reasonable attorney fees); Seyler v. Seyler, 678 F.2d 29, 31 (5th Cir. 1982) (damages of reasonable attorney fees); Bankers Trust Co. v. Publickcr Indus., $641 \mathrm{~F} .2 \mathrm{~d} \mathrm{1361,} 1368$ (2d Cir. 1981) (damages in sum of $\$ 10,000$ or appellee's expenses, including attorney fees, whichever is less); Bank of Canton v. Republic Nat'l Bank, 636 F.2d 30, 31 (2d Cir. 1980) (damages of $\$ 5,000$ or expenses including counsel fees, whichever is less); Church of Scientology v. McLean, 615 F.2d 691, 693 (5th Cir. 1980) (damages include reasonable attorney fees); Libby, McNeill \& Libby v. City Nat'l Bank, 592 F.2d 504, 515 (9th Cir. 1979) (damages of reasonable attorney fees); Mancuso v. Indiana Harbor Belt R.R., 568 F.2d 553, 554 (7th Cir. 1978) (damages of $\$ 350$ as attorney fees); Overmyer v. Fidelity \& Deposit Co., 554 F.2d 539, 543 (2d Cir. 1977) (damages of $\$ 2,000$ in attomey fees); First Nat'l Ins. Co. v. Lynn, 525 F.2d 1, 3 (1st Cir. 1975) (damages to the extent of the reasonable fees of the attorneys); Ginsburg v. Stern, 295 F.2d 698, 698 (3d Cir. 1961) (usual costs plus $\$ 500$ for counsel fees and other expenses), cert. denied, 368 U.S. 987 (1962); Lowe v. Willacy, 239 F.2d 179, 180 (9th Cir. 1956) (just damages of double costs and attorney fces).

120. See, e.g., Shuffman v. Hartford Textile Corp., 659 F.2d 299, 306 (2d Cir. 1981) $(\$ 5,000)$, cert. denied, 455 U.S. 1018 (1982); Ruderer v. Fine, 614 F.2d 1128, 1133 (7th Cir. 1980) (\$2,500); Clarion Corp. v. American Hoine Prod. Corp., 494 F.2d 860, 866 (7th Cir.) (\$2,500), cert. denied, 419 U.S. 870 (1974); Fluoro Elec. Corp. v. Branford Assoc., 489 F.2d 320, 326 (2d Cir. 1973) $(\$ 4,500)$.

121. See, e.g., TIF Instruments, Inc. v. Collette, 713 F.2d 197, 201 (6th Cir. 1983); Ellingson v. Burlington N., Inc., 653 F.2d 1327, 1332 (9th Cir. 1981); Self v. Self, 614 F.2d 1026, 1028 (5th Cir. 1980) (per curiam); Exhibitors Poster Exch., Inc. v. Natioual Screen Serv. Corp., 543 F.2d 1106, 1107 (5th Cir. 1976), cert. denied, 431 U.S. 938 (1977); Furbee v. Vantage Press, Inc., 464 F.2d 835, 838 (D.C. Cir. 1972); Eaton v. New Hanover County Bd. of Educ., 459 F.2d 684, 686 (4th Cir. 1972).

122. See, e.g., Brady v. Chemical Constr. Corp., 740 F.2d 195, 202 (2d Cir. 1984) (additional thrce percent on judgment); Oscar Gruss \& Son v. Lumbermens Mut. Casualty Co., 422 F.2d 1278, 1285 (2d Cir. 1970) (additional four percent on judgment).

123. See supra note 120 . 
3. Attorney Fees. Under the "American Rule," the prevailing party can not ordinarily recover attorney fees as a part of the costs assessable against the losing party. ${ }^{124}$ As the Supreme Court pointed out in Roadway Express, ${ }^{125}$ however, this rule does not apply when the litigation is initiated or conducted in bad faith. ${ }^{126}$ Attorney fees can be imposed as a sanction expressly under 28 U.S.C. § 1927, as damages under 28 U.S.C. $\$ 1912$ and Appellate Rule 38, and under the court's inherent authority as recognized in Roadway Express. ${ }^{127}$ Attorney fees account for the largest inonetary sanctions because, in inost cases, they are the largest finite anount the court can identify as damages flowing froin the taking of a frivolous appeal and can be ascertained with relative ease.

4. Fines. Occasionally a court will impose a inonetary sanction on a litigant or attorney and describe the sanction as a fine. ${ }^{128}$ The difference between a fine and dainages, of course, is that a fine is paid to the court while damages are paid to the appellee. The basis for fines against an attorney is the court's disciplinary authority over attorneys. ${ }^{129}$ Presumably, the purpose of the fine is to compensate for the harm done to other hitigants or the public by wasting the court's tine, while the purpose of damages is to coinpensate the appellee for the harm the delay has caused him.

5. Persons Assessed. Monetary sanctions can be imposed on either the litigant or the attorney. Both 28 U.S.C. $§ 1912$ and Appellate Rule 38 provide for the award of damages and costs to a party, but neither specifies who is to pay the damages or costs-the party or his counsel. ${ }^{130}$ Generally, however, when the courts lold attorneys liable for a sanction, they cite 28 U.S.C. \& 1927. ${ }^{131}$ That section is by its terms applicable only to attorneys and others admitted to conduct cases

124. See Alyeska Pipeline Serv. Co. v. Wilderness Soc'y, 421 U.S. 240, 247 (1975) (detailed history of development of rule); McCandless v. Great Atl. \& Pac. Tea Co., 697 F.2d 198, 200 (7th Cir. 1983).

125. 447 U.S. 752 (1980).

126. Id. at $765-66$.

127. See supra notes $83-88$ and accompanying text.

128. See In re Bithoney, $486 \mathrm{~F} .2 \mathrm{~d}$ at 325 (suspending attorney as member of the bar and imposing fine of \$500); see also Prossmitz, supra note 70, at 36.

129. See supra notes $95-98$ and accompanying text.

130. See supra notes 68 and 75.

131. See, e.g., Wood v. Santa Barbara Chamber of Commerce, 699 F.2d 484, 485 (9th Cir. 1983), cert. denied, 104 S. Ct. 1445 (1984); but see Asberry v. United States Postal Serv., 692 F.2d 1378, 1382 (Fed. Cir. 1982) (costs and fees assessed jointly and severally against appellant and his attorney); Browning Debenture Holders' Comm. v. DASA Corp., 605 F.2d 35, 41 (2d Cir. 1978) (attorncy also one of the appellants). 
before federal courts. ${ }^{132}$ According to Roadway Express, both the appellant and the attorney inay be ordered to pay the attorney fees of the opposing party under the court's inherent authority. ${ }^{133}$

\section{B. Nonmonetary Sanctions.}

The major nonmonetary sanction that can be imposed against a party for taking a frivolous appeal or for abusive tactics is to dismiss the appeal or affirm the judgment. ${ }^{134}$ Dismissal or affirmance, however, is not considered a sanction for the taking of a frivolous appeal because the result is no different from that in an appeal not found frivolous but im which the judgment is still affirmed. Dismissal or affirmance is a inajor sanction, however, if it is based on the misconduct of the party or the attorney and imposed on an otherwise legitimate appeal. No court of appeals has dismissed an appeal for this reason, although district courts dismiss cases for abusive tactics relating to discovery. ${ }^{135}$ Courts of appeals have, however, imitiated disciplinary proceedings against attorneys who pursue frivolous appeals. ${ }^{136}$ These proceedings could result in the imposition of a monetary sanction, a nonmonetary sanction, or both. ${ }^{137}$ Appellate courts have also censured attorneys in judicial opimons, ${ }^{138}$ and have warned that any similar conduct in the future would result in disciplinary action. ${ }^{139}$ One court of

132. 28 U.S.C. $§ 1927$ (1982) ("attorney or other person admitted to conduct cases").

133. 447 U.S. at 766.

134. See supra note 99 and accompanying text.

135. See, e.g., CTS Corp. v. Piher Int'l Corp., 59 F.R.D. 394, 395 (N.D. Ill. 1973) (citing FEDeral Rule of Civil Procedure 37(b)(2)(C)).

136. See, e.g., Lowenschuss v. Bluhdorn, 613 F.2d 18, 19 (2d Cir.) (request to Pennsylvania Bar Association to review attorneys' conduct), cert. denied, 449 U.S. 840 (1980); In re Bithoney, 486 F.2d 319, 319 (lst Cir. 1973) (disciplinary proceedings in response to court's request in Panagopoulos v. INS, 434 F.2d 602, 604 (1st Cir. 1970)).

137. See In re Bithoney, 486 F.2d 319, 325 (1st Cir. 1973) (suspension and imposition of fine).

138. See, eg., Umited States v. Potamkin Cadillac Corp., 697 F.2d 491, 495 (2d Cir.) (attorney "has unduly delayed the termination of this litigation and has caused the proceedimgs to be unreasonably and vexatiously multiplied"), cert. denied, 103 S. Ct. 3128 (1983); Shuffman v. Hartford Textile Corp., 659 F.2d 299, 305 (2d Cir. 1981) ("the attorney who is responsible for the unreasonable prolongation of this litigation"), cert. denied, 455 U.S. 1018 (1982); Lowenschuss v. Bluhdorn, 613 F.2d 18, 20 (2d Cir.) ("culmination of pattern of highly improper conduct on his [attorney's] part”), cert. denied, 449 U.S. 840 (1980); Der-Rong Chour v. INS, 578 F.2d 464, 469 (2d Cir. 1978) ("double costs are assessed petitioner and his attorney"), cert. denied, 440 U.S. 980 (1979); Acevedo v. INS, 538 F.2d 918, 921 (2d Cir. 1976) ("petitioner's attorney who is responsible for the unreasonable prolongation of this higation"); $c f$. In re Complaint of Judicial Misconduct, 2 Ct. Cl. 255, 262 (1983) ("Attorneys . . have violated their responsibihties as members of the bar [and for] this misconduct they are publicly reprimanded."). See also Flaherty v. Flaherty, $31 \mathrm{Cal}$. 3d 637, 651-54, 646 P.2d 179, 188-90, 183 Cal. Rptr. 508, 517-19 (1982) (discussing public censure for frivolous appeals and the need for due process).

139. See, e.g., Watson v. Callon Petroleum Co., 632 F.2d 646, 649 (5th Cir. 1980) ("[We] trust that our message is understood."); Comora v. Security Title Ins. Co., 614 F.2d 683, 684 (9th Cir. 
appeals has enjoined a litigant from bringing bad faith law suits and appeals that raise unoriginal issues. ${ }^{140}$

\section{ANALYSIS}

\section{A. Confusion Over Defining Frivolous Appeals and Determining When To Impose a Sanction.}

The courts of appeals have often confused two distinct issues. The first issue is whether an appeal should be classified as frivolous because of its lack of merit.141 The second issue is whether, given that an appeal is frivolous on its merits, the conduct of the appellant or the attorney is such that a sanction should be imposed on one or both. ${ }^{142}$ Often courts determine that an appeal is frivolous by examining the conduct of the appellant or attorney, rather than by looking at the merits of the appeal. ${ }^{143}$ This conduct is then used as the basis for determining the necessity for the sanction and the type to be imposed. 144 This approach causes the courts to vacillate between objective and subjective standards and obscures the extent to which the intent of the appellant or the attorney determines whether an appeal is frivolous.

Even though an appeal does have some merit, it may still be frivolous if the appellant's conduct imdicates that his primary purpose is to delay enforcement of the judgment, to cause the appellee to incur unnecessary expense, to be vexatious, or if the conduct otherwise demonstrates bad faith by abuse of the judicial process. There is no case im which a court has found that an appeal had merit and yet was conducted in such a way as to call for a frivolous appeal sanction. What the courts have done, however, is to look at the conduct of the appellant as evidence of whether the appeal is without merit and thus frivolous. ${ }^{145}$ This type of analysis creates confusion. A frivolous appeal should be one that has no merit when viewed objectively and should not be defined by the beliefs or intent of the appellant or attorney.

1980) ("[A]ppellant should note that it would be unlikely that we would be so constrained if he attempts, once again, to relitigate these issues."); Overmyer v. Fidelity \& Deposit Co., 554 F.2d 539, 543 n.4 (2d Cir. 1977) ("We will not countenance further attempts to pervert the federal judicial process into a Dickensian Court where lawsuits never end.").

140. See Green v. Warden, 699 F.2d 364, 367-70 (7th Cir.) (court issues injunction under the All Writs Act, 28 U.S.C. § 1651(a), against prisoner's abuse of judicial system), cert. denied, $103 \mathrm{~S}$. Ct. 2436 (1983). See also Browning Debenture Holders' Comm. v. DASA Corp., 605 F.2d 35, 38 (2d Cir. 1978) (court upheld district judge's permanent injunction against "further harassing litigation" against the defendants).

141. See supra notes $28-37$ and accompanying text.

142. See supra notes $38-52$ and accompanying text.

143. See id.

144. See id.

145. See id. 
This does not mean, however, that the conduct of the appellant or the attorney is irrelevant to the frivolous appeal sanction. What it does mean is that the conduct is significant for another purpose-to determine the nature and extent of the sanction to be imposed. This is the real reason the courts look to the conduct and the intent it deinonstrates. The more fiagrant the conduct, the clearer it is that the intent or motive of the person is culpable and the larger the sanction should be. Thus, the conduct or intent should be the nieasure of the sanction, not the measure of the merit of the appeal.

If the appeal is found to have some merit when viewed objectively, does this mean that the conduct or intent of the party or attorney then becomes irrelevant? Clearly not. Roadway Expressit4 has established beyond question that a party or attorney who abuses the judicial process by conducting litigation in bad faith has engaged in conduct that justifies the imposition of sonie type of sanction, either nionetary or nonmonetary, without regard to the underlying merit of the lawsuit. ${ }^{147}$ At the trial level, the recent amendment to Federal Rule of Civil Procedure 11 goes beyond Roadway Express and provides for monetary or nonmonetary sanctions-agaimst the litigant, the attorney, or both-for the filing of any pleading, niotion, or other paper in court that does not meet the standard set forth in Rule 11.148 Under that rule, signing a document filed in court certifies that it is "well grounded in fact and is warranted by existing law or a good faith argument for the extension, nodification, or reversal of existing law and that it is not interposed for any improper purpose, such as to harass or to cause unnecessary delay or needless increase in the cost of hitigation." 149 Each document must meet a dual standard; it must have merit and must not be filed for an improper purpose. A violation of either standard is grounds for a sanction. The amended rule also deletes the wilfulness requirenient of the old rule, so that all that need be shown to justify the sanction is a failure to comply with the rule. ${ }^{150}$ The extent of the sanction will, of

146. 447 U.S. 752 (1980).

147. Id. at 766 .

148. If a pleading, motion or other paper is signed in violation of this rule, the court, upon motion or upon its imitiative, shall impose upon the person who signed it, a represented party, or both, an appropriate sanction, which may include an order to pay to the other party or parties the amount of the reasonable expenses incurred because of the filing of the pleading, motion or other paper, including a reasonable attorney's fee.

Fed. R. CIV. P. 11. See Comment, Sanctions in the Proposed Amendments to the Federal Rules of Civil Procedure: Some Questions About Power, 11 Hofsrra L. Rev. 997 (1983).

149. Fed. R. Civ. P. 11.

150. Federal Rule of Civil Procedure 11 formerly read: "For a wilful violation of this rule an attorney may be subjected to appropriate disciplinary action." Fed. R. Civ. P. 11, 28 U.S.C.A. (West 1960) (emphasis added). The amended rule now reads: "If a pleading . . . is signed in 
course, depend upon the nature of the conduct involved. Similar provisions were added to Federal Rules of Civil Procedure 16151 and 25.152

\section{B. Sources of Authority.}

When imposing sanctions for frivolous appeals, courts often fail to specify whether they are relying on a section of the United States Code, Appellate Rule 38, a circuit rule, the court's inherent authority, or some combination of these. Part of the problem is that the courts have no uniform procedure for considering the question of sanctions and usually discuss thein only at the end of the opimion on the inerits. The problem is particularly acute when the court is acting sua sponte rather than in response to a inotion filed by the appellee, because a motion or supporting memoranduin will likely cite a statute or rule as the basis for the motion. Another difficulty is that 28 U.S.C. $\S 1912$ and Appellate Rule 38 are essentially duphicative and the courts will often refer to one or the other or both without discussing the relationship between them. The courts leave unresolved the issues whether section 1912 and Appellate Rule 38 authorize the imposition of a sanction against only the appellant, whether the attorney can be hable under that section or rule, or whether the attorney can be liable under section 1927 or the court's inherent authority. Further comphications include whether section 1912 and Appellate Rule 38 require a showing of delay. ${ }^{153}$ Another unresolved question is whether the court can require that the sanction be paid to the court, thus giving it the characteristics of a fine. ${ }^{154}$

These problems and others stein primarily froin the fact that sections 1912 and 1927 of the Judicial Code were developed separately and had different purposes. ${ }^{155}$ Section 1912 was intended to remedy injury to the appellee resulting froin the delay caused by an appeal, while section 1927 was concerned with abuse of the judicial process by

violation of this rule, the court . . . shall impose upon the person . . . an appropriate sanction ... ." Fed. R. Crv. P. 11.

151. "In lieu of or in addition to any other sanction, the judge shall require the party or the attorney representing him or both to pay the reasonable expenses incurred because of any noncompliance with this rule including attorney's fees . . ." FED. R. Clv. P. 16 (emphasis added).

152. "If certification is made in violation of the rule, the court, upon motion or upon its own initiative, shall impose upon the person who made the certification, the party on whose behalf the request, response, or objection is made, or both, an appropriate sanction, which may include an order to pay the amount of the reasonable expense incurred because of the violation, including a reasonable attorney's fee." FED. R. CIV. P. 26.

153. See supra notes $68-69,75-82$ and accompanying text.

154. See supra notes $113-23,128-29$ and accompanying text.

155. See supra notes $68-74$ and accoinpanying text. 
attorneys, primarily at the trial level. 156 The Supreme Court rules prior to 1980 and the circuit rules based on them were drafted to limit the damages that could be awarded under section 1912.157 Appellate Rule 38 , although it appears to be a grant of power, is simply a replication of section 1912 and does not establish any enforcement procedure. ${ }^{158}$ The advisory committee note to Appellate Rule 38 includes a cross reference only to section 1912 and not to section 1927 and thus it is unclear whether there is any relationship between the two.

\section{Procedure for Imposing Sanctions.}

Courts seldom consider whether any special procedural requirements must be met in order to impose a sanction for a frivolous appeal. The impetus of the sanction can come from either the appellee or the appellate court itself. ${ }^{159}$ If the appellee initiates the process, the appellant or his attorney then has an opportunity to respond to the motion prior to the court's decision. Under this procedure the appellant is accorded the basic due process of notice and opportunity to be heard. The same is not true, however, if the court first raises the question of a sanction agamst the appellant or his attorney. ${ }^{160}$ In these cases the first time that the offending person discovers the possibility of a sanction is when the court files its opinion imposmg the sanction. The appellant or attorney in such a case has neither notice nor opportunity to be heard prior to the imposition of the sanction.

Given the fundamental due process requirements of notice and the opportumity to be heard, it is surprising that there are only three instances in which procedure has been discussed-in a United States Supreme Court opimion, ${ }^{161}$ a congressional committee report, ${ }^{162}$ and an opimion of the California Suprcme Court. ${ }^{163}$ Although the courts of

\section{See id.}

157. See supra notes $80-82$.

158. See supra notes $75-82$ and accompanying text.

159. For party motions, see, for example, Watson v. Callon Petroleum Co., 632 F.2d 646, 648 (5th Cir. 1980); Fluoro Elec. Corp. v. Branford Assocs., 489 F.2d 320, 322 (2d Cir. 1973). For courts raismg sanctions sua sponte, see Van Arnem Co. v. ClS Leasing Corp., No. 80-1258, No. 80-1275 (6th Cir. Jan. 5, 1982) (available Aug. 1, 1983 on LEXIS, Genfed library, Cir file); McCoy v. Gordon, 709 F.2d 1060, 1061 (5th Cir. 1983); Ruderer v. Fines, 614 F.2d 1128, 1132 (7th Cir. 1980); Clarion Corp. v. American Home Prod. Corp., 494 F.2d 860, 865 (7th Cir.), cert. denied, 419 U.S. 870 (1974).

160. See Flaherty v. Flaherty, 31 Cal. 3d 637, 652, 646 P.2d 179, 188-89, 183 Cal. Rptr. 508, 517-18 (1982) (finding merit in appellant's claim that his due process rights were violated when he was fined by the court sua sponte for a frivolous appeal without notice and a hearing).

161. See infra notes $165-66$ and accompanying text.

162. See infra note 168 and accompanying text.

163. See infra notes $169-72$ and accompanying text. 
appeals have discussed procedural requirements in relation to the imposition of sanctions by district courts, they have not discussed the procedures necessary im the appellate courts. ${ }^{164}$

In Roadway Express, the United States Supreme Court, holding that a federal court had the inherent power to require counsel to pay the attorney fees of opposing parties when counsel has "abused the processes of the courts," stated that such a sanction could be imposed only after fair notice and an opportunity to be heard have been provided. 165 The dccision, of course, was directcd at the exercise of a district court's inherent power over attorneys, ${ }^{166}$ and thus may not directly control the exercise of a court of appeals' power under a statute or rule. There is no suggestion in the Roadway Express opinion, however, that a lesser requirement might be applicable in an appellate court.

After the Roadway Express decision, Congress amended 28 U.S.C. $\S 1927$ to include attorney fees among the items that could be assessed agamst counsel pursuant to that section. ${ }^{167}$ The report of the conference committee managers, specifically addressing the issue of what procedures should be followed in imposing a sanction under the section, stated: "The managers imtend that judges applymg section 1927 will safeguard the rights of an attorney who may be held in violation of the section. Before sanctioning an attorney under section 1927, the court is to afford the attorney all appropriate protections of due process available under the law."168 The report, however, did not spell out what these appropriate due process protections were to include.

The California Supreme Court, in Flaherty v. Flaherty, reviewed an appellate court's summary imposition of a $\$ 500$ fine agamst an at-

164. For a discussion of district court procedures, see, for example, Textor v. Board of Regents, 711 F.2d 1387, 1395 (7th Cir. 1983) (subsequent hearing at which attorney bore burden of proving that the award was not justified did not cure defect of no prior hearing); United States v. Blodgett, 709 F.2d 608, 610 (9th Cir. 1983) (im order to impose a sanction against conduct which occurred outside presence of district court, the court must give counsel the opportunity to explain conduct); $c$. Knorr Brake Corp. v. Harbil, Inc., 738 F.2d 223, 227-28 (7th Cir. 1984) and Miranda v. Southern Pac. Transp. Co., 710 F.2d 516, 522 (9th Cir. 1983) (sanctions should not bc imposed by trial court without procedural protections).

The issue of appellate court procedures was raised in an opinion dissenting to the imposition of a sanction under section 1927, but was not discussed in the majority opinion. See Malhiot v. Southern California Retail Clerks Union, 735 F.2d 1133, 1138-39 (9th Cir. 1984) (Boochever, J. concurring in part and dissenting in part).

165. Roadway Express, 447 U.S. at 766-67.

166. Id at $765-66$.

167. 28 U.S.C. $\S 1927$ (1982).

168. H. R. Rep. No. 1234, 96th Cong., 2d Sess. 8, reprinted in 1980 U.S. Code ConG. \& AD. NEwS 2781, 2783. 
torney for filing a frivolous appeal. ${ }^{169}$ The court reversed the imposition of the fine and held that "[f]undamental constitutional mandates require that the basic protections of due process be followed before an attorney is fined for prosecuting a frivolous appeal. . . . Constitutional due process principles are offended by the summary imposition of sanctions by the appellate courts." 170 The court went on to define what process was due in the type of case before it, concluding that before a sanction can be imposed against an attorney for filing a frivolous appeal, the court inust give the attorney fair warning and an opportunity to respond, and then hold a hearing. ${ }^{171}$ If a sanction is imposed, a written statement of reasons for the penalty must also be given. ${ }^{172}$

This inquiry raises several discrete questions: (1) whether the required notice must precede the imposition of the sanction; (2) whether the opportunity to be heard must include an oral hearing; and (3) whether an attorney may receive fewer procedural due process safeguards than a litigant receives.

The Supreme Court has stated that the "root" requirement of due process is the right to be heard, and that the right to be heard depends upon adequate notice of the right. ${ }^{173}$ An appellate court considering a sanction sua sponte could be required, for example, to notify the appellant by an order to show cause, which would serve the same function as a motion filed by the appellee. Although there are arguments that prior notice is not necessary before imposing a sanction for a frivolous appeal, ${ }^{174}$ failure to afford prior notice would seem to violate Roadway

169. Flaherty v. Flaherty, 31 Cal. 3d 637, 645, 646 P.2d 179, 184, 183 Cal. Rptr. 508, 513 (1982).

170. Id. at 652,646 P.2d at $188-89,183$ Cal. Rptr. at 517-18.

171. Id. at 654, 646 P.2d at 190, 183 Cal. Rptr. at 519 .

172. Id. In a separate opinion, one justice said that due process in many cases would require only an opportunity to file a written argument, and that an oral hearing was not always required. Id. at 654, 646 P.2d at 190, 183 Cal. Rptr. at 519 (Newman, J., concurring in part and dissenting in part).

173. See, e.g., Mathews v. Eldridge, 424 U.S. 319,333 (1976) ("The fuudamental requirement of due process is the opportunity to be heard 'at a meaningful time and in a meaningful manner.' ") (quoting Armstrong v. Manzo, 380 U.S. 545, 552 (1965)).

174. There are two arguinents that prior notice is not necessary. One is that sections 1912 and 1927 and Appellate Rule 38 themselves give notice that a sanction is possible and the court is merely enforcing the statute or rule. The existeuce of the statute or rule, however, does not elininate the necessity for notice of an enforcement effort; it serves, rather, as the basis for the enforcement action. It has also been suggested that because of the opportunity to seek reconsideration of the sanction imposed by the appellate court, notice is provided by the opinion or order imposing the sanction, and an opportunity to be heard is provided by a nootion for recousideration with supporting memorandum. Again, this reasoning is not very convincing. The opportuuity to persuade a court not to impose a sanction can hardly be said to be the procedural equivalent of persuading a court to rescind its action. The former is much more likely to result in a court approaching the issue with an open mind. 


\section{Express. ${ }^{175}$}

The courts have provided no uniform definition of a hearing, and have emphasized that the type of hearing required will vary from case to case. ${ }^{176}$ Courts seldom discuss whether an oral hearmg is necessary when a motion is made in the appellate court. ${ }^{177}$ The oral argument on the merits is the only oral portion of the appellate process, and in many cases even the merits are decided on the basis of briefs with no oral argument. ${ }^{178}$ Various motions are uniformly inade and acted upon without an oral hearing. Appellate Rule 27, which governs motions in the courts of appeals, does not require an oral hearing on any type of motion, substantive or procedural. ${ }^{179}$ Consequently, there does not appear to be any more reason to require an oral hearing on a motion for a frivolous appeal sanction than on any other type of motion. ${ }^{180}$

An attorney is expressly subject to sanctions under 28 U.S.C. $\S 1927$ and Appellate Rule 46 and has been held hable under 28 U.S.C. $\S 1912,{ }^{181}$ Appellate Rule $38,{ }^{182}$ and the court's inherent authority. ${ }^{183}$

175. Prior notice is required only when the court is considering a sanction. The court is not required to notify the appellant before finding that an appeal is frivolous, because that deternination is based on the court's assessinent of the record. The appellant has already had an opportunity to convince the court of the merits of his appeal through briefs and oral argument.

176. See, e.g., Mathews v. Eldridge, 424 U.S. 319, 334-35 (1976) (specific dictates of due process require considerations of three factors: private interest affected, risk of erroneous deprivation through procedures used, and fiscal and adininistrative burden of additional procedural requirement).

177. See Flaherty v. Flaherty, 31 Cal. 3d 637, 654-55, 646 P.2d 179, 190, 183 Cal. Rptr. 508, 519 (Newman, J., concurring in part and dissenting in part) ("[T]oo many judges still fail to think in tenns of possibly requiring notice and opportunity for informal response."). In all of the cases in which federal courts of appeals have considered sanctions for frivolous appeals, the necessity for an oral hearing has never been raised. When the United States Supreme Court in 1983 imposed for the first time in many years a monetary sanction for the taking of a frivolous appeal, it did so without hearing oral argument on the issue. See Tatuin v. Regents, 103 S. Ct. 3084 (1983).

178. See R. Martineau, supra note 4, at $\$ 12.2$.

179. FED. R. APP. P. 27.

180. The type of evidence examined by the appellate court when it considers whether an appeal is frivolous is another factor suggesting that an oral hearing is unnecessary. Such a hearing does not serve a fact-finding function; the court looks only at the record in the case before it and at other cases im which the appellant or attorney was involved. These are inatters of which the court can take judicial notice. The court itself is the best judge of whether the appeal is legally frivolous, and the appellant already has had an opportunity to denionstrate his view of the legal merits of the appeal. When the court considers whether the appeal was conducted in bad faith, it again examines only the record, and the only issue to be resolved is the inferences to be drawn from that record. The appellant can state his side of the arguinent in a written docuinent just as well as he can in oral argument.

181. See United States v. Potamkin Cadillac Corp., 697 F.2d 491, 494 (2d Cir.), cert. dented, 103 S. Ct. 3128 (1983).

182. See Wood v. Santa Barbara Chamber of Cominerce, Inc., 699 F.2d 484, 485 (9th Cir. 1983), cert. denied, 104 S. Ct. 1445 (1984).

183. See Roadway Express, 447 U.S. at $764-67$ (1980); see also supra note 88. 
The attorney, because of his admission to practice in the court, has a different relationship to the court than does a litigant. The Supreme Court cases on point suggest that an attorney in a disciplinary proceeding, despite this special relationship, is entitled to the same basic due process protections as a layinan. ${ }^{184}$ Appellate Rule $46(\mathrm{c})$ requires that before a federal court of appeals can take disciplinary action against an attorney for conduct unbecoming a neinber of the bar, for failure to comply with the Federal Rules of Appellate Procedure, or for violating any court rule, the court must give the attorney notice, an opportunity to show cause, and a hearing if requested. ${ }^{185}$ Both Appellate Rule $46(\mathrm{~b}),{ }^{186}$ governing suspension or disbarment, and Appellate Rule 46(c) distinguish between responding in writing to an order to show cause and requestimg a hearing. This suggests that a "learing" as used in these rules refers to an oral hearing. However, when a court imposes a monetary sanction under sections 1912 or 1927, Appellate Rule 38, or the court's inherent authority, it is not acting pursuant to Appellate Rule 46. Therefore, it does not appear that the requirements of Appellate Rule 46 would apply. ${ }^{187}$ Due process does require at the very least that the court notify, by means of an order to show cause, the person against whom it is considering imposing a sanction. ${ }^{188}$

184. See Roadway Express, 447 U.S. at 767 (sanctions against attorneys "should not be assessed lightly or without fair notice and an opportunity for a hearing on the record"); In re Ruffalo, 390 U.S. 544, 550 (1968) (lawyer charged with misconduct in disbarment proceeding is entitled to procedural due process, which includes fair notice). See Martineau, The Supreme Court and State Regulation of the Legal Profession, 8 HASTings ConST. L.Q. 199, 216-20, 241-43 (1981).

185. Federal Rule of Appellate Procedure 46(c) provides: "A court of appeals inay, after reasonable notice and an opportunity to show cause to the contrary, and after hearing, if requested take any appropriate disciplinary action . . . ."

186. Federal Rule of Appellate Procedure 46(b) provides: "The ineinber shall be afforded an opportunity to show good cause ... . Upon his response to the rule to show cause, and after hearing, if requested . . . the court shall enter an appropriate order."

187. Even if an oral hearing is required, it need not be before a panel of the appellate court. It would be counterproductive for judges to spend time conducting learings on whether to impose a frivolous appeal sanction when one of the purposes of the sanction is to save judges tine by discouraging frivolous appeals. If a hearing is necessary, there is no reason wlyy it could not be conducted by the circuit executive, clerk, or some other nember of the staff of the court of appeals. The staff member could develop a record, hear any evidence or explanation of the appellant or attorney, and inake recommendations to a panel of the court that would then decide whether to impose a sanction and the amount.

188. See Roadway Express, 447 U.S. at 767 n.14. However, the Court noted that " $[\mathrm{t}]$ he due process concerns posed by an outright dismissal are plainly greater than those presented by assessing counsel fees against lawyers." Id.

This procedure should not delay rendition of a judginent on the merits of the appeal. If the sanction is imposed after the mandate is issued, the sanction can be imposed by separate order or by amending the inandate. See $\mathrm{R}$. MARTINEAU, supra note 4 , at $\S 17.1$. 


\section{Proposals}

Before discussing the specifics of any proposal, one inust consider whether the Federal Rules of Appellate Procedure may authorize a court of appeals to impose a sanction and establish the range of sanctions for frivolous appeals. If the imposition of a sanction for filing a frivolous appeal or for abusing the appeal process abridges or modifies a substantive right, it is beyond the rulemaking power granted by the Rules Enabling Act. ${ }^{189}$ It cannot be argued, however, that any effort to penalize the exercise of the right to appeal is an abridgement of the Act and thus can be authorized only by another statute. The imposition of a sanction does not abridge the right to appeal any inore than do other rules that put limits on the exercise of statutory rights. ${ }^{190}$ More importantly, a court of appeals does have the power to dismiss an appeal it finds to be frivolous. ${ }^{191}$ Under the rationale of Roadway Express, if a court can disnniss an appeal because it is frivolous, it can impose a sanction for the saine reason. ${ }^{192}$

Further, if the court can impose a sanction under its inherent authority, the saine inatter can be regulated by the appellate rules. The Supreine Court, in its new Rule 49.2, expressly gives itself the authority to impose a sanction for a frivolous appeal. ${ }^{193}$ Present Appellate Rule 38 , although its title refers to damages for delay, is phrased in terms of "frivolous appeal" rather than in terms of delay. ${ }^{194}$ Both of these rules are clear precedent for the proposition that a rule authorizing the imposition of a sanction for taking a frivolous appeal does not contravene the Rules Enabling Act. ${ }^{195}$ More importantly, the subject of regula-

189. 28 U.S.C. $\$ 2072$ (1982) ("[s]uch rules shall not abridge, enlarge or modify any substantive right").

190. In fact, the Federal Rules of Appellate Procedure themselves limit the right to appeal. See, e.g., FED. R. APP. P. 4 (m civil cases, notices of appeals of right must be filed within 30 days after entry of the order or judgment).

191. See supra note 99.

192. Roadway Express, 447 U.S. at 765 . The Court cited its decision in Link v. Wabash Ry. Co., 370 U.S. 626 (1962), for the proposition that courts have the inherent power to dismiss. Since the assessment of monetary sanctions is less severe than outright dismissal, the court reasoned that Link also supported the authority of courts to impose those sanctions. Roadway Express, 447 U.S. at 765 .

193. SUP. CT. R. 49.2 ("When an appeal or petition for writ of certiorari is frivolous, the Court may award the appellee or the respondent appropriate damages.").

194. See supra note 75 and accoinpanyimg text.

195. There is even less validity to the argument that a substantive right is abridged when a litigant or attorney is penalized for abusing the appellate process by filing motions or other documents in bad faith or for some inotive other than to prosecute the appeal. Federal Rule of Civil Procedure 11, as recently amended, and Federal Rule of Civil Procedure 37 both authorize the use of sanctions for acts of commission or onission that interfere with the normal functioning of the judicial process in the district court. The Supreme Court lias upheld the validity of the Federal 
tions governing the use of sanctions is a matter that appears more appropriate for appellate rules than for a statute, because the use of sanctions for these purposes by the courts is essentially a matter of selfprotection. The judicial power has long been thought to include the power of the courts to protect theinselves from any attempts to interfere with the proper functioning of the courts and the judicial process. ${ }^{196}$ The necessity for self-protection is the basis for the concept of inherent power.

There may be some concern that the deterrent effect of a sanction will discourage the good faith appellant or attorney from filing a legitimate appeal or motion. ${ }^{197}$ This is, at most, a theoretical problem. The first Congress, which established the right to appeal every final judginent, recognized that the riglit could be abused and that monetary sanctions were an appropriate vehicle for deterring that abuse. ${ }^{198}$ The history of the use of sanctions by appellate courts does not suggest that the courts will misuse or overuse this authority. ${ }^{199}$ If anything, the record deinonstrates that the threat of sanctions lias had minimal effect because the courts have been so reluctant to use them.

Because of the probleins associated witl the current pieceineal approach to frivolous appeals, ${ }^{200}$ a single new statute or rule should be established as the exclusive basis for sanctioning frivolous appellate conduct. A rule that attempts to reduee both the number of meritless appeals and abusive tactics should deal with four main areas: (1) frivolous appeals; (2) abusive appeal tactics; (3) the range of sanctions; and (4) procedures for initiating consideration of a sanction. ${ }^{201}$

\section{A. Frivolous Appeals.}

The first section of an amended Appellate Rule 38 sliould simply authorize the iniposition of a sanction for the taking of a frivolous ap-

Rule of Civil Procedure 37 sanction, see Roadway Express, 447 U.S. at 763-64; National Hockey League v. Metropohtan Hockey Club, Inc., 427 U.S. 639, 643 (1976), and it is likely that Federal

Rule of Civil Procedure 11 will also be approved.

196. See Roadway Express, 447 U.S. at 765-67; Link v. Wabash Ry. Co., 370 U.S. 626, 629-32

(1962) (inherent power allows court to dismiss sua sponte for lack of prosecution).

197. See supra note 15 and accompanying text.

198. See supra note 68 and accompanying text.

199. See supra notes $68-74$ and accompanying text.

200. See supra notes $155-58$ and accompanying text.

201. Appellate Rule 38 is the logical basis for frivolous appeals sanctions, and should be amended to address these areas. Section 1912 should be repealed, but section 1927 should be retained, since it also applies to conduct in the trial courts. See supra note 73 and accompanying text. 
peal. ${ }^{202}$ The first section should not attempt to define precisely a frivolous appeal, but should simply state that it is an appeal with no reasonable legal or factual basis. A frivolous appeal must meet some objective standard, but that standard is best left to the courts to address on a case-by-case basis. The standard applied should be objective and not subjective; issues of a subjective nature, such as the intent of the appellant, are relevant only to the sanction to be imposed.

Statutes and rules may be stated in mandatory or permissive terms. The recent revision of Federal Rule of Civil Procedure 11 directs, rather than authorizes, the district court to levy a sanction for filing a paper in violation of the rule. ${ }^{203}$ The advisory committee note to the amended rule states that this choice was inade to "focus the court's attention on the need to impose sanctions for pleading and motion abuses."204 The note acknowledges, lowever, that the court "retams the necessary flexibility to deal appropriately with violations of the rule. It has discretion to tailor sanctions to the particular facts of the case . . ."205 In other words, the imposition of the sanction is mandatory; the type and size of the sanction is discretionary. This same philosophy should be followed when imposing a sanction for taking a frivolous appeal.

The bad faith of the appellant, as demonstrated by lis conduct at the trial, on appeal, and in prior or other pending litigation, becomes significant only when the court considers the type of sanctions to be imposed, ${ }^{206}$ and should not be used to determine whether the appeal is frivolous in the first place.

The rule should apply to attorneys as well as to parties. The attorney, rather than the party, may be the primcipal actor in taking the appeal. Attorneys are expressly the subject of 28 U.S.C. $\$ 1927$ and have also been held liable when sanctions are imposed under other sources of authority. ${ }^{207}$ Agam, revised Federal Rule of Civil Procedure 11, which provides for the imposition of a sanction upon a party, the attorney or both, is the model for the appellate rule. ${ }^{208}$ It will be up to the court to ascertain who, in any particular case, is the person at fault.

202. There is no need to hist or describe here the range of sanctions. See infra notes $217-22$ and accompanying text.

203. "If a pleading, motion, or other paper is signed in violation of this rule, the court . . . shall impose . . . an appropriate sanction . . . ." FED. R. Clv. P. 11 (emphasis added).

204. FED. R. Clv. P. 11 advisory committee note.

205. Id.

206. See supra notes 38-52 and accompanying text.

207. See supra notes $130-33$ and accompanying text.

208. "[T]he court . . . shall impose upon the person who signed it, a represented party, or both, an appropriate sanction . ..." FED. R. Clv. P. 11. 
The rule should include a reference to initiating a proceeding as well as to taking an appeal. In a court of appeals, parties often file petitions for supervisory writs as a substitute for appeal. ${ }^{209}$ These proceedings can be frivolous in the sane way as an appeal and thus should be included in the section. Furthermore, if a legitimate appeal becomes frivolous as a result of later developments, ${ }^{210}$ continumg the appeal should also be sanctioned.

The first section of the rule should read:

(a) A court of appeals shall impose a sanction upon a party or attorney or both for taking or continuing an appeal or initiating a proceeding in the court that the court finds to be frivolous. For purposes of this rule, a frivolous appeal is one that has no reasonable legal or factual basis.

\section{B. Abusive Appeal Tactics.}

The fact that appellants and their attorneys abuse the appellate process by various tactics has long been recognized. ${ }^{211}$ When these tactics are used in connection with an appeal that can be objectively defined as frivolous, the tactics used on the appeal are relevant in determining the sanction iniposed for taking the frivolous appeal. ${ }^{212}$ If an appeal does in fact have some inerit and thus cannot properly be classified as frivolous, it does not follow that a sanction cannot or should not be inposed for the improper conduct. This is the thrust of 28 U.S.C. $\S 1927$, but that section applies only to attorneys and not to parties. ${ }^{213}$ It is also the thrust of the Roadway Express decision. ${ }^{214}$ Some courts, in an effort to penalize this type of conduct, use the conduct to conclude that an appeal is frivolous. This confusion can best be avoided by including in an appellate rule a provision similar to amended Rule 11 of the Federal Rules of Civil Procedure. Such a provision would make it clear that whether or not an appeal is found to be frivolous, abusive appeal tactics should be penalized.

The appellate rule should contain the same elements as does amended Federal Rule of Civil Procedure 11; the imposition of the

209. See R. Martineau, supra note 4 , at $\$ 19.1$.

210. If, during the pendency of an appeal, there is a retroactive change in the relevant law, adverse to the appellant, continuing the appeal may be frivolous. $C f$. Christiansburg Garment Co. v. EEOC, 434 U.S 412, 422 (1978) (a plaintiff can be assessed his opponent's attorney fees if "a court finds that his claim was frivolous, unreasonable, or groundless, or that the plaintiff continued to hitigate after it clearly became so"). See also Seegull Mfg. Co. v. NLRB, 735 F.2d 971, 974 (6th Cir. 1984).

211. See supra notes $81-82$ and accompanying text.

212. See supra notes $141-52$ and accompanying text.

213. See supra notes $70-74$ and accoinpanying text.

214. See supra notes $83-88$ and accompanying text. 
sanction should be mandatory, but the type and size of the sanction should be within the discretion of the judge. A paper filed in court should be signed by the person filing it, with the signature constituting a certification that the paper is supported by the facts, by existing law, or by a good faith argument for changing the law, and that the paper is not filed for an improper purpose such as delay, harassment, or a needless mcrease in the cost of hitigation.

The language of the section should be virtually identical to that of Rule 11, so that the saine type of improper conduct will receive equal treatment $i m$ the court of appeals and in the district court. Cases interpreting one rule may serve as precedent for interpretations of the other.

One difference between Rule 11 and the new appellate rule should be the separation of the requirement that papers be signed from the directive for the imposition of a sanction. Because present Appellate Rule 25 already deals with filing and service of papers, ${ }^{215}$ adding the signature requirement and its status as a certification in Rule 25(a) with a cross reference to Appellate Rule 38, where the penalty for filing a paper in violation of the certification is stated, is preferable.

The new language of Appellate Rule 25 should read:

(a) A party or attorney who files a paper in a proceeding conducted pursuant to these rules shall sign the paper. The signature of the party or attorney or the filing of a paper without a signature constitutes a certification that: the docuinent is well grounded in fact; is warranted by existing law or a good faith argument for thc extension, modification, or reversal of existing law; and is not filed for an inproper purpose such as to harass or to cause unnecessary delay or needless increase in the cost of the litigation. A party or attorney who files a paper in violation of this rule, or the party on whose behalf the paper is filed, is subject to a sanction in accordance with Rule 38.

Moreover, unlike Federal Rule of Civil Procedure 11, the new appellate rules would apply to conduct beyond the filing of papers. Although that is the type of activity most likely to fall within the meaning of "abusive appeal tactic," it is not necessarily the only abusive tactic. The new Rule should also sanction the failure to file or the late filing of a paper such as a record or brief; failure to order the transcript in a timely manner; failure to appear for a settleinent conference or oral argument; a dilatory response to an order or request from the court or a request from the other party; or any act of commission or omission that has the same improper purposes inentioned in Rule 11-delay, harass-

215. Federal Rule of Appellate Procedure 25 is entitled "Filing and Service." It has four subsections, entitled "Filing," "Service of All Papers Required," "Manner of Service," and "Proof of Service." 
ment, or causmg needless expense. ${ }^{216}$ Consequently, the appellate rule must include a general reference to any abusive appeal tactic which would mclude, but not be limited to, filing a paper with an improper purpose.

The new section to be added to Appellate Rule 38 should read:

(b) A court of appeals shall impose a sanction upon a party or attorney or both for filing a paper in violation of Rule 25(a) or for any act of commission or omission that has an improper purpose such as to harass or to cause unnecessary delay or needless increase in the cost of litigation.

\section{Available Sanctions.}

The section on sanctions should, to the extent possible, give flexibility to the court while at the same time giving some advance warning to litigants and attorneys. This can best be achieved by listing the most common types of sanctions, but allowing the court to fashion a different sanction when appropriate. ${ }^{217}$

One sanction that should be included is the power to dismiss the appeal. Although dismissal is not actually a sanction for a frivolous appeal, ${ }^{218}$ a dismissal will not necessarily occur $\mathrm{m}$ a case of abusive tactics absent its use as a sanction. The inclusion of dismissal as a sanction for abusive tactics is supported by Roadway Express ${ }^{219}$ and by its customary use as a sanction for discovery abuses pursuant to Federal Rule of Civil Procedure 37.220

Fines payable to the court are not included as a sanction in any present statute or rule. Monetary sanctions have been used by the courts of appeals as a means of compensating the opposing party for the delay or additional expense caused by the appellant or his attorney. ${ }^{221}$ The court itself, however, may have been put to additional expense because of the conduct of a party or attorney even though the opposing party has not been directly harmed. It may also be that the

216. See supra note 149 and accompanying text.

217. This approach represents a coinpromise between providing an exclusive list of sanctions and leaving the question of sanctions entirely to the discretion of the conrts. Both approaches have precedent in existing law. Appellate Rule 38, 28 U.S.C. $\$ 1912$ (1982), and Supreme Court Rule 49.2 each lists damages as a sanction, and Appellate Rule 38 and section 1912 also allow double costs. See supra note 103 and accompanying text. On the other hand, the new Federal Rule of Civil Procedure 11 leaves the entire matter to the discretion of the court, providing that "the court. . . shall impose ... an appropriate sanction . . . ."

218. See supra notes $99-100$ and accompanying text.

219. 447 U.S. at 754. See supra note 84.

220. See, e.g., CTS Corp. v. Piher Int'l Corp., 59 F.R.D. 394, 395 (N.D. III. 1973) (citing FED. R. Crv. P. 37(b)(2)(C)).

221. See supra notes 15 and 16. 
harm is borne primarily by other litigants who suffer delay in the disposition of their cases. In those situations, deterrence is the principal reason for a sanction, 222 and a fine payable to the court rather than damages payable to the opposing party is the most appropriate sanction.

The third section of Appellate Rule 38 should read:

(c) A court of appeals may impose one or more of the following sanctions:

(1) dismissal of the appeal;

(2) striking a paper, pleading or motion;

(3) a monetary sanction including but not limited to (i) double costs, (ii) a penalty not to exceed ten percent of the judginent, (iii) dainages occasioned by delay, (iv) reasonable attorney fees, (v) a fine payable to the court; and

(4) any other sanction appropriate in the circunstances of the case.

\section{Procedure.}

Prior notice of the possibility of a sanction inust be given either by a motion filed by an opposing party or by an order to show cause issued by the court. ${ }^{223}$ The only opportunity to be heard required by due process guarantees is the opportunity for the party or attorney to present his views in writing to the court prior to the court's decision on whether to impose a sanction. ${ }^{224}$ To accomplish this, the fourth section of Appellate Rule 38 should read:

(d)(1) A party inay by motion request that a sanction be imposed upon another party or attorney pursuant to this rule.

(2) If a court on its own initiative considers that a sanction pursuant to this rule may be appropriate, the court shall order the party or attorney to show cause in writing wliy a sanction should not be iniposed on the party or attorney or both.

\section{CONCLUSION}

Frivolous appeals and abusive hitigation tactics have long been a problem for the federal appellate courts. ${ }^{225}$ The statutes and court rules prescribing sanctions to deal with these problems have been used only sporadically and often without a clear understanding of the relationship ainong the various statutes and rules and of the separate

222. See supra note 19 and accompanying text.

223. See supra notes $173-75$ and accompanying text.

224. See supra notes $\mathbf{1 7 6 - 8 0}$ and accoinpanying text.

225. See, e.g., Whitney v. Cook, 99 U.S. 607, 607 (1878) (award of danages for frivolous appeals favored over dismissal); Wimchester v. Jackson, 7 U.S. (3 Cranch) 515, 515 (1806) (writ of error dismissed with costs for want of jurisdiction). 
problems each is intended to address. Courts have wavered between objective and subjective standards im determining when an appeal is frivolous and when a sanction should be imposed. The opinions have revealed the confusion of the courts, and this confusion has obscured the objectives of the statutes and rules. As a consequence, except in the most extreme cases, there is presently little deterrence of frivolous appeals and abusive appeal tactics.

Until recently, the failure of the federal appellate courts to define clearly the type of appeal or conduct that would subject a party or attorney to a sanction and their reluctance to impose sanctions had no great effect on their caseload. In the past two decades, however, increased litigation has had a dramatic impact on the federal appellate courts with a concomitant increase in the number of meritless appeals and actions taken by appellants or their attorneys that have no purpose other than to harass or delay. It has now becoine a matter of priority for the federal appellate courts to recognize clearly the type of conduct that should be prevented and to use their powers to impose sanctions to achieve that goal.

There are a number of problems with the present provisions: The statutes and rules overlap; courts have difficulties in recognizing offensive conduct; and there is no clear procedure for the imposition of sanctions. The best solution to these problems is to promulgate a single rule that: (1) directs a federal appellate court to impose a sanction for the taking or continuation of a frivolous appeal or other proceeding, or for engaging in abusive tactics in the prosecution of an appeal or other proceeding in an appellate court; (2) prescribes the range of sanctions that a court can impose; and, (3) establishes the procedure to be followed before a sanction can be imposed. In addition, a rule coinparable to recently annended Federal Rule of Civil Procedure 11 should be adopted, nnaking the signing of a paper filed in court a certification that it is not filed for an improper purpose. To accomplish this, Rule 38 of the Federal Rules of Appellate Procedure should be revised to read as follows:

(a) A court of appeals shall impose a sanction upon a party or attorney or both for taking or continuing an appeal or imitiating a proceeding in the court that the court finds to be frivolous. For purposes of this rule, a frivolous appeal is one that has no reasonable legal or factual basis.

(b) A court of appeals shall impose a sanction upon a party or attorney or both for filing a paper in violation of Rule 25(a) or for any act of commission or omission that has an improper purpose such as to harass or to cause unnecessary delay or needless increase in the cost of litigation. 
(c) A court of appeals may impose one or more of the following sanctions:

(1) dismissal of the appeal;

(2) striking a paper, pleading or motion;

(3) a inonetary sanction including but not limited to (i) double costs, (ii) a penalty not to exceed ten percent of the judgment, (iii) damages occasioned by delay, (iv) reasonable attorney fees, (v) a fine payable to the court;

(4) any other sanction appropriate in the circumstances of the case.

(d) (1) A party may by motion request that a sanction be imposed upon another party or attorney pursuant to this rule.

(2) If a court on its own initiative considers that a sanction pursuant to this rule may be appropriate, the court shall order the party or attorney to show cause in writing why a sanction should not be imposed on the party or attorney or both.

Rule 25 of the Federal Rules of Appellate Procedure should be amended to include a new section (a) to precede the present section (a). The new section should read:

(a) A party or attorney who files a paper in a proceeding conducted pursuant to these rules shall sign the paper. The signature of the party or attorney or the filing of a paper without a signature constitutes a certification that: the docuinent is well grounded in fact; is warranted by existing law or a good faith argument for the extension, modification, or reversal of existing law; and is not filed for an improper purpose such as to harass or to cause unnecessary delay or needless increase ill the cost of the hitigation. A party or attorney who files a paper in violation of this rule, or the party on whose behalf the paper is filed, is subject to a sanction in accordance with Rule 38.

If these proposals are adopted, the federal appellate courts will be in a better position to deter both the flow of frivolous appeals and the use of the appellate process for improper purposes. The accomplishment of these two objectives will benefit both the appellate courts and all who must rely upon them for the resolution of appeals in a just and expeditious inanner. 